NBER WORKING PAPER SERIES

\title{
CONSUMER SPENDING AND THE ECONOMIC STIMULUS PAYMENTS OF
} 2008

Jonathan A. Parker

Nicholas S. Souleles

David S. Johnson

Robert McClelland

Working Paper 16684

http://www.nber.org/papers/w16684

\author{
NATIONAL BUREAU OF ECONOMIC RESEARCH \\ 1050 Massachusetts Avenue \\ Cambridge, MA 02138 \\ January 2011
}

For helpful comments, we thank two anonymous referees, Jeffrey Campbell, Adair Morse, Joel Slemrod, seminar participants at Berkeley, the Board of Governors of the Federal Reserve System, Boston University, Columbia, Duke Fuqua, the Federal Reserve Bank of Chicago, Kellogg, Michigan, MIT Sloan, Princeton, Stanford, Wisconsin and Wharton, and participants in presentations at the 2009 ASSA meeting, the Fall 2010 NBER Economic Fluctuations and Growth Research Meeting, and the 2011 Society for Economic Dynamics Annual Meeting. We thank the staff of the Division of Consumer Expenditure Surveys at the Bureau of Labor Statistics for their work in getting the economic stimulus payment questions added to the Consumer Expenditure Survey. Parker thanks the Zell Center at the Kellogg School of Management for funding. The views expressed in this research, including those related to statistical, methodological, technical, or operational issues, are solely those of the authors and do not necessarily reflect the official positions or policies of the U.S. Census Bureau or the Congressional Budget Office, or the views of other staff members. The views expressed in this paper are those of the authors and do not necessarily correspond to those of the U.S. Census Bureau, the Bureau of Labor Statistics, or the National Bureau of Economic Research.

NBER working papers are circulated for discussion and comment purposes. They have not been peerreviewed or been subject to the review by the NBER Board of Directors that accompanies official NBER publications.

(C) 2011 by Jonathan A. Parker, Nicholas S. Souleles, David S. Johnson, and Robert McClelland. All rights reserved. Short sections of text, not to exceed two paragraphs, may be quoted without explicit permission provided that full credit, including (C) notice, is given to the source. 
Consumer Spending and the Economic Stimulus Payments of 2008

Jonathan A. Parker, Nicholas S. Souleles, David S. Johnson, and Robert McClelland

NBER Working Paper No. 16684

January 2011, Revised March 2013

JEL No. D12,D14,D91,E21,E62,E65,H24,H31

\begin{abstract}
We measure the response of household spending to the economic stimulus payments (ESPs) disbursed in mid-2008, using special questions added to the Consumer Expenditure Survey and variation arising from the randomized timing of when the payments were disbursed. We find that, on average, households spent about $12-30 \%$ (depending on the specification) of their stimulus payments on nondurable expenditures during the three-month period in which the payments were received. Further, there was also a substantial and significant increase in spending on durable goods, in particular vehicles, bringing the average total spending response to about $50-90 \%$ of the payments. Relative to research on the 2001 tax rebates, these spending responses are estimated with greater precision using the randomized timing variation. The estimated responses are substantial and significant for older, lower-income, and home-owning households. We find little evidence that the propensity to spend varies with the method of disbursement (paper check versus electronic transfer).
\end{abstract}

Jonathan A. Parker

Finance Department

Kellogg School of Management

Northwestern University

2001 Sheridan Road

Evanston, IL 60208-2001

and NBER

Jonathan-Parker@Kellogg.Northwestern.edu

Nicholas S. Souleles

Finance Department

The Wharton School 2300 SH-DH

University of Pennsylvania

Philadelphia, PA 19104-6367

and NBER

souleles@wharton.upenn.edu
David S. Johnson

US Census Bureau

Room 7H174

Washington, DC 20233-8500

david.s.johnson@census.gov

Robert McClelland

Suite 3105

2 Massachusetts Ave NE

Washington DC 20212-0001

McClelland.Robert@bls.gov 
In the winter of 2007-08, facing the fallout from an increasingly severe financial crisis and already contemplating the limitations of traditional monetary policy, Congress and the Administration turned to fiscal policy to help stabilize the U.S. economy. The Economic Stimulus Act (ESA) of 2008, enacted in February 2008, consisted primarily of a 100 billion dollar program that sent economic stimulus payments (ESPs) to approximately 130 million U.S. tax filers. The desirability of this historically-important use of fiscal policy depends critically on the extent to which these tax cuts directly changed household spending, as well as on any subsequent multiplier or price effects.

In this paper, we measure the direct spending effect caused by the receipt of the ESPs, the existence of which is a necessary (though not sufficient) condition for the efficacy of this counter-cyclical policy. We begin by measuring the average spending response of households, using variation in the randomized timing of when the ESPs were disbursed. Further, to help improve our understanding of consumption in this recession and our models of consumer behavior in general, we also analyze the heterogeneity in the spending response across households with different characteristics and across different categories of consumption expenditures.

We measure the change in household spending directly caused by the receipt of the ESPs by using a natural experiment provided by the structure of the tax cut. The ESPs varied across households in amount, method of disbursement, and timing. Typically, single individuals received $\$ 300-\$ 600$ and couples received $\$ 600-\$ 1200$; in addition, households received $\$ 300$ per child that qualified for the child tax credit. Households received these payments through either paper checks sent by mail or electronic funds transfers (EFTs) into their bank accounts. Most importantly, within each disbursement method, the timing of receipt was determined by the final two digits of the recipient's Social Security number (SSN), digits that are effectively randomly assigned. ${ }^{1}$ We exploit this random variation to cleanly estimate the causal effect of the receipt of the payments on household spending, by comparing the spending of households that received

\footnotetext{
${ }^{1}$ The last four digits of an SSN are assigned sequentially to applicants within geographic areas (which determine the first three digits of the SSN) and a "group" (the middle two digits of the SSN).
} 
payments in a given period to the spending of households that received payments in other periods.

To conduct our analysis, we worked with the staff at the Bureau of Labor Statistics (BLS) to add supplemental questions about the payments to the ongoing Consumer Expenditure (CE) Survey, which contains comprehensive measures of household-level expenditures for a stratified random sample of U.S. households. These supplemental questions ask CE households to report the amount and month of receipt of each stimulus payment they received, as well as the method of disbursement of each payment (mailed paper check versus EFT). The responses to these questions allow us to measure the impact of the payments on the spending of CE households and study the extent to which the method of disbursement influences the propensity to spend.

Summarizing our main findings, on average households spent about $12-30 \%$ of their stimulus payments, depending on the specification, on non-durable consumption goods and services (as defined in the CE survey) during the three-month period in which the payments were received. This response is statistically and economically significant. Although our findings do not depend on any particular theoretical model, the response is inconsistent with both Ricardian equivalence, which implies no spending response, and with the canonical life-cycle/permanent income hypothesis (LCPIH), which implies that households should consume at most the annuitized value of a transitory increase in income like that induced by the one-time stimulus payments. We also find a significant effect on the purchase of durable goods and related services, primarily the purchase of vehicles, bringing the average response of total CE consumption expenditures to about $50-90 \%$ of the payments during the three-month period of receipt.

These results are statistically and economically broadly consistent across specifications that use different forms of variation, including specifications that focus on the randomized timing variation within each of the two disbursement methods. The estimated spending responses are statistically and economically similar for ESPs received by EFT compared to those received by mail, although there is little temporal variation in the former group with which to identify the key effect. We also find some evidence of an ongoing though smaller response in the subsequent three-month period following that of ESP receipt. While this response cannot be estimated with precision, it does provide evidence that the spending effects are not immediately reversed. 
For comparison, Johnson, Parker, and Souleles (2006) (JPS) estimates that in 2001, upon receipt of a tax rebate, household spending on nondurable goods rose on average by 20 to 40 percent of the tax rebate (depending on the specification), a response which is just slightly larger than the response estimated here across similar specifications. ${ }^{2}$ However, we find larger total spending in 2008 due to significant spending on durable goods. While some of this difference may be due to sampling error, it may also partly reflect some of the differences in the details of the tax cut and economic environment in 2008 compared to 2001. For instance, some prior research finds that larger payments can skew the composition of spending towards durables, which is consistent with our findings given that the 2008 stimulus payments were on average about twice the size of the 2001 rebates. ${ }^{3}$ That said, the overall pattern of results is broadly similar for 2001 and 2008, and so our findings suggest some robustness in the response of consumers to the broad-based tax rebates employed in these two most recent and important recessions.

To be clear, our methodology is unable to estimate the complete effect of the ESP program on aggregate consumption. This is because we estimate only the spending caused by the receipt of an ESP and correlated with the timing of receipt (in particular not including any spending at the time of announcement). Also, our methodology cannot estimate the general equilibrium effects of the policy (any multiplier or price effects). Keeping these issues in mind, our results suggest a significant macroeconomic effect of the 2008 ESPs on aggregate consumption demand. The point estimates imply that the ESPs directly caused an increase in consumer demand for CE-defined nondurable expenditures of $\$ 33$ to $\$ 80$ billion (at an annual rate) in the second quarter of 2008 and $\$ 15$ to $\$ 36$ billion (at an annual rate) in the third quarter.

\footnotetext{
${ }^{2}$ In subsequent work, Misra and Surico (2011) also find estimates in this range when applying quantile regressions to the JPS data. Trimming the top and bottom $1 \%$ of the dependent variable reduces the JPS baseline average response of nondurable goods (Douglas Hamilton pointed out a similar result to us), but the result again stays within the reported cross-specification range. Other trimmed versions of the JPS results are largely unchanged (e.g. the response of low income or asset households) or increase (e.g. the effect on total spending).

${ }^{3}$ While JPS finds no significant response of durable goods in 2001, Souleles (1999) finds a significant increase in both nondurable and durable goods (in particular auto purchases) in response to spring-time Federal income tax refunds, which are substantially larger than the 2001 tax rebates. Federal tax refunds currently average around \$2500 per recipient, whereas the average rebate in 2001 came to about \$480 (JPS). (Aaronson, Agarwal, and French (2008), Leininger, Levy, and Schanzenbach (2010), and Wilcox (1989) also find a significant response in durable goods to changes in income. See also Barrow and McGranahan (2000) and Adams, Einav, and Levin (2009) for related results for the earned income tax credit and for subprime auto sales, respectively.) Finally, temporary subsidies to purchase prices induce inter-temporal substitution and so can cause large increases in durables purchases but also later declines (Mian and Sufi, 2010). By contrast, tax rebates are likely to operate through wealth and liquidity effects, which theoretically do not imply such large reversals.
} 
Our estimates for total CE spending imply a direct increase of about 1.3 to 2.3 percent of personal consumption expenditures (PCE) in the second quarter, and 0.6 to 1.0 percent of PCE in the third quarter (again at annual rates). ${ }^{4}$ We return to these numbers in the conclusion, but here note again that these direct effects on nominal spending demand may have also led to higher prices (not only increases in real spending) and/or additional spending through multiplier effects.

As for results that further inform theories of consumer behavior and credit markets, across households, the responses are largest for older and low-income households, groups which have substantial and statistically significant spending responses. According to the point estimates, the responses are largest for high-asset households, but this result is not statistically significantly different from zero and assets are not as well measured in the CE survey. Further, motivated by the collapse of the housing market in 2008, we find that homeowners on average spent more of their ESPs than did renters, a difference that is statistically significant at the ten percent level.

This paper is structured as follows. Sections I and II briefly describe the literature and relevant aspects of ESA 2008. Section III describes the CE data and Section IV sets forth our empirical methodology. Section $\mathrm{V}$ presents the main results regarding the short-run response to the economic stimulus payments, while Section VI examines the longer-run response. Sections VII and VIII examine the differences in response across different households, and across different categories of expenditure, respectively. After a concluding section, the Appendices contain additional information about ESA 2008 and the data.

\section{Related Literature}

Of the many papers that test the consumption-smoothing implications of the rationalexpectations LCPIH, the most closely related to our work is the set of papers that uses household-level data and quasi-experiments to identify the effects on consumption caused by predictable changes in income, including in particular income changes induced by tax policy.

\footnotetext{
${ }^{4}$ These figures are based on estimates in Tables 4 and 5 and so omit statistically-insignificant lagged spending. The calculations assume that the contemporaneous estimates represent spending done in the month of receipt and the month after. Using estimates from Table 7 that include lagged spending effects, the corresponding estimates are, for nondurable expenditures, $\$ 66$ billion in the second quarter and \$75 billion in the third, and for total spending, $\$ 198$ billion in the second quarter and $\$ 227$ billion in the third, or 1.9 and 2.2 percent of PCE respectively.
} 
Deaton (1992), Browning and Lusardi (1996), JPS, and Jappelli and Pistaferri (2010) review these literatures well. ${ }^{5}$

Our paper is most closely related to JPS, which uses a similar module of questions appended to the CE survey to study the 2001 income tax rebates. JPS finds a relatively large response in nondurable expenditure, amounting to about $20-40 \%$ of the rebates on average (depending on the specification) during the three-month period in which they were received, but no significant response in durable goods. Unlike the current study, however, JPS is unable to identify the response of nondurables with precision using only the random variation in timing of rebate receipt. JPS finds larger than average responses for households with low liquid wealth or low income, and a significant though decaying lagged spending effect, so that on average roughly two-thirds of the rebates was spent cumulatively during the quarter of receipt and subsequent three-month period. ${ }^{6}$

Agarwal, Liu, and Souleles (2007) finds consistent results using credit card data and direct indicators of being credit constrained; in particular, the spending responses are largest for consumers that are constrained by their credit limits. Shapiro and Slemrod (2003a) finds, using the Michigan Survey of Consumers, that about $22 \%$ of respondents who received (or expected to receive) a 2001 rebate report that they will mostly spend their rebate. The authors calculate that, under certain assumptions, this result implies an average marginal propensity to consume (MPC) of about one third, which is consistent with the short-run response of expenditure in JPS estimated from data on actual spending and rebate receipt.

A few other studies also investigate the 2008 ESPs. First, using scanner data on a subset of nondurable retail goods in the first few weeks after the payments started to be disbursed, Broda and Parker (2008) finds that spending on such goods increased by a significant amount, $3.5 \%$ in the four weeks after payment receipt. The increase is larger than average for low asset and low income households. Second, using data from a payday lender, Bertrand and Morse (2009) finds that receipt of an ESP initially reduces the probability of taking out a payday loan. The magnitude of the reduction in debt is modest relative to the ESPs, and, after two cycles, borrowing returns to its pre-ESP level on average. For the most constrained borrowers, by

\footnotetext{
${ }^{5}$ For a survey of recent fiscal policy, see e.g., Auerbach and Gale (2010).

${ }^{6}$ Johnson, Parker, and Souleles (2009) finds qualitatively similar responses to the 2003 child tax credit payments using CE data. Coronado, Lupton, and Sheiner (2006) also study the 2003 child payments, using the Michigan Survey.
} 
contrast, debt does not decline, consistent with the spending dynamics discussed in Agarwal, Liu, and Souleles (2007).

Third, Shapiro and Slemrod (2009) uses the Michigan Survey to analyze the 2008 stimulus payments, and finds similar results as in Shapiro and Slemrod (2003a), with about 20\% of respondents self-reporting that they will mostly spend their payment. This again corresponds to an average MPC of about one third. This response is larger than expected under the LCPIH for a transitory tax cut, and it implies a noticeable expansionary effect on aggregate consumption in the second and third quarters of 2008. The Michigan survey results provide no clear evidence of greater spending by low-income or potentially constrained households. ${ }^{7}$

Finally, Bureau of Labor Statistics (2009) reports various summary statistics about the CE data on the ESPs and self-reported usage. Nearly half of CE households reported that they used their ESP mostly to pay down debt, 18\% reported they mostly saved their ESP, and 30\% reported that they mostly spent it, more than found in Shapiro and Slemrod (2009).

\section{The 2008 Economic Stimulus Payments}

ESA 2008 provided ESPs to the majority of U.S. households (roughly 85\% of "tax units"). The ESP consisted of a basic payment and -- conditional on eligibility for the basic payment -- a supplemental payment of $\$ 300$ per child that qualified for the child tax credit. To be eligible for the basic payment, a household needed to have positive net income tax liability, or at least sufficient "qualifying income". ${ }^{8}$ For eligible households, the basic payment was generally the maximum of $\$ 300$ ( $\$ 600$ for couples filing jointly) and their tax liability up to $\$ 600$ (\$1,200 for couples). Households without tax liability received basic payments of $\$ 300$ ( $\$ 600$ for

\footnotetext{
${ }^{7}$ In 2008 , of the 80 percent of respondents who report they will mostly save their ESP, the majority (about 60 percent) report that they will mostly pay down debt (as opposed to accumulate assets). See also Sahm, Shapiro and Slemrod (2010). The Michigan Survey includes additional subjective questions about expected future spending. Of respondents who said they will initially mostly use the rebate to pay down debt, most report that they will "try to keep [down their] lower debt for at least a year." (There are analogous results for respondents who said they will save by accumulating assets.) The Survey included similar questions in 2001 and yielded similar results (Shapiro and Slemrod, 2003b). By contrast, using data on actual spending in 2001, Agarwal, Liu, and Souleles (2007) finds that, while on average households initially used some of their rebates to increase credit card payments and thereby pay down debt, the resulting liquidity was soon followed by a substantial increase in spending.

${ }^{8}$ While the stimulus payments were commonly referred to as "tax rebates," strictly speaking they were advance payments for credit against tax year 2008 taxes. To expedite the disbursement of the payments, they were calculated using data from the tax year 2007 returns (and so only those filing 2007 returns received the payments). If subsequently a household's tax year 2008 data implied a larger payment, the household could claim the difference on its 2008 return filed in 2009. However, if the 2008 data implied a smaller payment, the household did not have to return the difference.
} 
couples), so long as they had at least $\$ 3,000$ of qualifying income (which includes earned income and Social Security benefits, as well as certain Railroad Retirement and veterans' benefits). Moreover, the total stimulus payment phased out with income, being reduced by five percent of the amount by which adjusted gross income exceeded $\$ 75,000$ ( $\$ 150,000$ for couples). As a result, the stimulus payments were more targeted to lower-income households than were the 2001 tax rebates.

The key to our measurement strategy is that the timing of ESP disbursement was effectively randomized across households. Table 1 shows the schedule of ESP disbursement. ${ }^{9}$ For recipients that had provided the IRS with their personal bank routing number (i.e., for direct deposit of a tax refund), the stimulus payments were disbursed electronically over a three-week period ranging from late April to mid May. ${ }^{10}$ The IRS mailed a notice to the recipients in advance of the EFTs. Appendix A provides an example of this notice. For households that did not provide a personal bank routing number, the payments were mailed using paper checks over a nine-week period ranging from early May through early July. ${ }^{11}$ The recipients of these checks received a similar notice in advance of the checks. ${ }^{12}$ Importantly, within each disbursement method, the particular timing of the payment was determined by the last two digits of the recipients' Social Security numbers, which are effectively randomly assigned.

In aggregate the stimulus payments in 2008 were historically large, amounting to about $\$ 100$ billion, which in real terms is about double the size of the 2001 rebate program. According

\footnotetext{
${ }^{9}$ The IRS schedule reports the latest date by which the ESPs are supposed to have been received by households. Accordingly, as also discussed below, the payments were disbursed (i.e., put in the mail or electronically transferred to banks) slightly earlier.

${ }^{10}$ Payments were directly deposited only to personal bank accounts. Payments were mailed to tax filers who had provided the IRS with their tax preparer's routing number, e.g. as part of taking out a "refund anticipation loan". Such situations are common, representing about a third of the tax refunds delivered via direct deposit in 2007.

${ }^{11}$ Due to the electronic deposits, about half of the aggregate stimulus payments were disbursed by the end of May. While most of the rest of the payments came in June and July, taxpayers who filed their 2007 return late could receive their payment later than the above schedule. Since about 92 percent of taxpayers typically file at or before the normal April $15^{\text {th }}$ deadline (Slemrod et al., 1997), this source of variation is small. Nonetheless, we present results below that exclude such late payments. Finally, due to human and computer error, about 350,000 households (less than 1 percent) did not receive the child tax credit component of their ESP with their basic ESP. The IRS took steps to identify these households and sent all affected households paper checks for the amount due for just the child credit, starting in early July.

${ }^{12}$ For paper checks, the notices were mailed about a week before the checks were mailed. For EFTs, the notices were sent a couple of business days before the direct deposits were supposed to be credited. The recipients' banks were also notified a couple of days before the date of the electronic transfers, and some banks might have credited some of the electronic payments to the recipients' accounts a day or more before the official payment date. For example, some EFTs that had been scheduled to be deposited on Monday April 28 were reported to the banks on Thursday April 24, and some banks appear to have credited recipients' accounts on Friday April 25.
} 
to the Department of the Treasury (2008), \$79 billion in ESPs was disbursed in the second quarter of 2008, which corresponds to about $2.2 \%$ of GDP or $3.1 \%$ of PCE in that quarter. During the third quarter, $\$ 15$ billion in ESPs was disbursed, corresponding to about $0.4 \%$ of GDP or $0.6 \%$ of PCE. The stimulus payments constituted about two-thirds of the total ESA package, which also included various business incentives and foreclosure relief. ${ }^{13}$ This paper focuses on the stimulus payments, as recorded in our CE dataset.

\section{The Consumer Expenditure Survey}

The CE interview survey contains detailed measures of the expenditures of a stratified random sample of U.S. households. CE households are interviewed five times. After an introductory interview that collects demographic and income information, households are interviewed up to four more times, at three month intervals. In these second to fifth interviews, households report their expenditures during the preceding three months (the "reference period"). The CE survey also gathers some limited information about wealth. New households are added to the survey every month, so the data can be used to identify spending effects from ESPs disbursed in different months. We use the 2007 and 2008 waves of the CE data (which include interviews in the first quarter of 2009).

Special questions about the 2008 ESPs were added to the CE survey in interviews conducted between June 2008 and March 2009, which covers the crucial time during which the payments were disbursed. ${ }^{14}$ The questions were phrased to be consistent with the style of other CE questions and the 2001 tax rebate questions. The new questions asked households whether they received any "economic stimulus payments... also called a tax rebate" since the beginning of the reference period for the interview and, if so, the amount of each payment, the date it was received, and, going beyond the 2001 questions, whether it was received by check or direct deposit. These questions were asked in all five CE interviews. ${ }^{15}$ Appendix B contains the language of the CE survey questions.

\footnotetext{
${ }^{13}$ For more details on ESA, see e.g., CCH (2008) and Sahm, Shapiro and Slemrod (2010).

${ }^{14}$ Ideally, since some ESPs arrived in April, the survey would have been in the field in May, e.g. for respondents whose last interview was in May. We also added a second module of questions that asked households whether the payment led them "mostly to increase spending, mostly to increase savings, or mostly to pay off debt," similar to the question analyzed by Shapiro and Slemrod (2009). We analyze the answers to these questions elsewhere.

${ }^{15}$ In the introductory interview, the ESP reference period is the preceding one month.
} 
Turning to our use of the CE data, for each household-reference period, we follow JPS and sum all stimulus payments received by each household in that three-month period to create our main economic stimulus payment variable, ESP. We also follow JPS in our definition of expenditures. Specifically, we focus on a series of increasingly aggregated measures of consumption expenditures. First, we study expenditures on food, which include food consumed away from home, food consumed at home, and purchases of alcoholic beverages. Much previous research has studied such expenditure on food, largely because of its availability in most years of the Panel Study of Income Dynamics, but it is a narrow measure of expenditure. Our second measure of consumption expenditures is a subset of nondurable expenditures, denoted "strictly nondurable" expenditures, which follows Lusardi (1996) and includes CE categories like utilities, household operations, gas, personal care, and tobacco. Third, our broadest and main measure of spending on nondurable goods and services, denoted nondurable expenditures, follows previous research using the CE survey and includes semi-durable categories like apparel, health and reading materials. Finally, total expenditures also includes durable expenditures such as home furnishings, entertainment equipment, and auto purchases. ${ }^{16}$ Appendix $\mathrm{C}$ provides further details about the data.

For our analysis, we use only data on households that have at least one expenditure interview during the period in which the ESP questions were in the field. The resulting sample period starts with interviews in September 2007 (when period $t$ in equation (1) below covers expenditures in June to August 2007) and runs through interviews in March 2009 (when period $t+1$ covers December 2008 to February 2009). Also, we drop from the sample any household observation ( $t$ or $t+1)$ with implausibly low expenditures (the bottom $1 \%$ of nondurable expenditures in levels), unusually large changes in age or family size, and uncertain stimulus payment status. $^{17}$

\footnotetext{
${ }^{16}$ Unlike in JPS, we find that the spending effect on total expenditures in 2008 is estimated with relative statistical precision. This could in part reflect the larger number of payments (about 30 percent more) in the sample in 2008, and the larger size (over double) of these payments. Suggestive of an improvement in data quality, there is also a decline in the ratio of the standard deviation of the change in household-level expenditures to the average level of expenditures between 2001 and 2008 for all our major categories. This may be due to the CE survey's transition in 2003 from using survey booklets to using computer-assisted personal-interview (CAPI) software. The CE survey measures expenditures independent of the use of credit or debt, so the measured expenditure for durables purchased using financing is the full price of the durable, not just the down payment.

${ }^{17}$ Our initial analysis of the ESP data uncovered a peculiar pattern in the raw data. When we notified the BLS, they determined that there had been an internal processing error, and worked rapidly to release a corrected version of the ESP data. We use this corrected version.
} 
Figure 1 shows our calculations of the aggregate amount of ESPs reported in the raw CE data by month, and the corresponding amount of ESP disbursement reported in the Daily Treasury Statements (DTS) (Department of the Treasury (2008)). During 2008, the ESPs reported in the CE survey aggregate to $\$ 94.6$ billion, which is quite close to the $\$ 96.2$ billion in ESPs in the DTS data. The temporal pattern of ESP receipt is also broadly similar across the two sources, though the CE data has fewer ESPs reported during the peak month of May and more in the following months. This suggests the possibility that some households took time to notice their ESP receipt, or that there is some other tendency to report a somewhat later date of receipt than actually occurred.

Table 2 presents summary statistics for our final full sample and subsamples that we further analyze. The average value of ESP, conditional on a positive value, is a little below $\$ 1000$. Households that receive ESPs by EFT on average have slightly higher expenditures, are slightly younger, have higher incomes and liquid assets, and have larger ESPs, than households that receive the payments by mail.

Table 3 shows more information about the distribution of ESPs in our dataset. Panel A shows that, consistent with the payments specified by ESA, most reported ESPs are in multiples of $\$ 300$, with about $55 \%$ of reports reflecting the (maximum) basic payments of $\$ 600$ or $\$ 1,200$. Panel B shows the pattern of ESPs by interview reference period. During the expenditure reference period that covers the main time of disbursement of the payments (May - July), about two-thirds of households report receiving a payment.

\section{Empirical Methodology}

Consistent with specifications in the previous literature (e.g., Zeldes (1989), Lusardi (1996), Parker (1999), Souleles (1999), and JPS), our main estimating equation is:

$$
C_{i, t+1}-C_{i, t}=\Sigma_{s} \beta_{0 s}{ }^{*} \text { month }_{s, i}+\boldsymbol{\beta}_{1}{ }^{\prime} \boldsymbol{X}_{i, t}+\beta_{2} E S P_{i, t+1}+u_{i, t+1}
$$

where $i$ indexes households and $t$ indexes time, $C$ is either household consumption expenditures or their log; month represents a complete set of indicator variables for every period in the sample, used to absorb the seasonal variation in consumption expenditures as well as the average of all other concurrent aggregate factors; and $X$ represents control variables (here age and changes in family size) included to absorb some of the preference-driven differences in the growth rate of consumption expenditures across households. ESP $P_{i, t+l}$ represents our key stimulus 
payment variable, which takes one of three forms: i) the total dollar amount of payments received by household $i$ in period $t+1\left(E S P_{i, t+1}\right)$; ii) a dummy variable indicating whether any payment was received in $t+1\left(I\left(E S P_{i, t+1}>0\right)\right)$; and iii) a distributed lag of $E S P$ or $I(E S P>0)$, used to measure the longer-run effects of the payments. We correct the standard errors to allow for arbitrary heteroskedasticity and within-household serial correlation. As an extension, to analyze heterogeneity in the response to the payments, we interact $\operatorname{ESP}_{i, t+1}$ with indicators for different types of households. The key coefficient $\beta_{2}$ measures the average response of household expenditure to the arrival of a stimulus payment. ${ }^{18}$

Most of the recent literature on the LCPIH focuses on testing the null hypothesis that $\beta_{2}$ is zero using variation in predictable changes in income and the assumption that the residual $\left(u_{i, t+1}\right)$ is orthogonal to all information potentially known to a household at the start of period $t$, including the change in income (Chamberlain, 1984; Souleles, 2004). By contrast, we can use the randomized timing of ESP receipt to ensure orthogonality between the residual and the predictable change in income that comes with the arrival of an ESP. This allows us to estimate $\beta_{2}$ and thus measure the causal effect of the payments on expenditure, regardless of whether the LCPIH is true or not. Nonetheless, our estimate still provides a direct test of the LCPIH. ${ }^{19}$ The rational-expectations LCPIH (or Ricardian equivalence) implies that $\beta_{2}=0$. Even if instead households were actually surprised by the payment, $\beta_{2}$ should still be small under the LCPIH, because the one-time payment represents a transitory increase in income.

\section{The Short-Run Response of Expenditure}

This section estimates the short-run change in consumption expenditures caused by receipt of a stimulus payment, using the contemporaneous payment variables $E S P_{t+l}$ and

\footnotetext{
${ }^{18}$ Our empirical approach only estimates the spending response correlated with the timing of the payment receipt. Our approach cannot estimate the magnitude of any common response as may have occurred in anticipation of the payments, both because the passage of ESA cannot be separated from other aggregate effects captured by our time dummies, such as seasonality and monetary policy, and because there is no single point in time at which a tax cut went from being entirely unexpected to being entirely expected.

${ }^{19}$ Even though February 2008 can fall in period $t$ for some sample households receiving a payment, under our maintained assumptions, any effect of the announcement on spending due to the passage of ESA does not bias our estimate of $\beta_{2}$. Whenever information about the tax cuts underlying the ESPs became publicly available, whether preceding the actual passage of ESA or not, under the LCPIH any resulting wealth effects should be small, and should have arisen at the same time(s) for all consumers, so their average effects on expenditure would be picked up by the corresponding time dummies in equation (1). More importantly, heterogeneity in such wealth effects (or in $\beta_{2}$ ) should not be correlated with the timing of ESP receipt, so (the average) $\beta_{2}$ should still be estimated consistently.
} 
$I\left(E S P_{t+1}>0\right)$ in equation (1). We begin by estimating (the average) $\beta_{2}$ in the full sample using all available variation. While this variation is analogous to that used in most of the previous LCPIH literature, we can go further and assess the validity of this variation. We refine our identification strategy by dropping non-recipients and late recipients from our sample and by using only the variation in the timing of ESP receipt within each method of disbursement (check versus EFT). The following section estimates the lagged response to the payments. ${ }^{20}$

\section{A. Identification using variation across all households}

We begin by estimating equation (1) using all available households and using ESP as the key regressor, which utilizes all of the available information about the payments received by each household, including the dollar amount of the ESP. In Table 4, the first set of four columns displays the results of estimating equation (1) by ordinary least squares (OLS), with the dollar change in consumption expenditures as the dependent variable and the contemporaneous amount of the payment $\left(E S P_{t+1}\right)$ as the key independent variable. The resulting estimates of $\beta_{2}$ measure the average fraction of the payment spent on the different expenditure aggregates in each column, within the three-month reference-period in which the payment was received.

We find that, during the three-month period in which a payment was received, relative to the previous three-month period, a household on average increased its expenditures on food by about $2 \%$ of the payment, its strictly nondurable expenditures by $8 \%$ of the payment, and its nondurable expenditures by $12 \%$ of the payment. The third result is statistically significant. In the fourth column, total consumption expenditures increased on average by $52 \%$ of the payment, a substantial and statistically significant amount. This result is relatively precisely estimated, especially considering that the difference with the preceding results largely reflects durable expenditures, which are much more volatile than nondurable expenditures.

These results identify the effect of a payment from variation in both the timing of payment receipt and the dollar amount of the payment. While the variation in the payment amount is possibly uncorrelated with the residual in equation (1), the variation is not purely random since the payment amount depends upon household characteristics such as tax status, income, and number of dependents. Unlike most previous research, we can refine the variation that we use.

\footnotetext{
${ }^{20}$ In theory, consistent estimation of the contemporaneous effect in general requires the inclusion of lagged ESP regressors, however in practice the estimated effects change little with the inclusion or exclusion of lags.
} 
The remaining columns of Table 4 use only variation in whether a payment was received at all in a given period, not the dollar amount of payments received. The second set of columns in the table uses the indicator variable $I\left(E S P_{t+1}>0\right)$ in equation (1). In this case $\beta_{2}$ measures the average dollar increase in expenditures caused by receipt of a payment. The estimated responses again increase in magnitude across the successive expenditure aggregates. During the threemonth period in which a payment was received, households on average increased their nondurable expenditures by about $\$ 122$, which is statistically significant at the $7 \%$ level. Total expenditures increased by a significant $\$ 495$. Compared to an average payment of just under $\$ 1,000$, these results are consistent with the previous estimates in the first set of columns, which also used variation in the magnitude of the payments received.

As a robustness check, the third set of columns in Table 4 uses the change in log expenditures as the dependent variable. On average in the three-month period in which a payment was received, nondurable expenditures increased by $2.1 \%$, and total expenditures increased by $3.2 \%$. These are again statistically and economically significant effects. At the average ESP and level of nondurable and total expenditures (Table 2), these results imply propensities to spend of 0.120 and 0.364 respectively, which are consistent with, though slightly smaller than, the previous results in the table.

Finally, to estimate a value interpretable as a marginal propensity to spend upon payment receipt without using variation in payment amount, we estimate equation (1) by two-stage least squares (2SLS). We instrument for the payment amount, ESP, using the indicator variable, I(ESP $>0$ ), along with the other independent variables. As in the first four columns, $\beta_{2}$ then measures the fraction of the payment that is spent within the three-month period of receipt. As shown in the last set of columns in Table 4, the estimated marginal propensities to spend remain close in magnitude to those estimated in the first four columns, which did not treat ESP as potentially non-exogenous. The findings in Table 4 are generally robust across a number of additional sensitivity checks. ${ }^{21}$

\footnotetext{
${ }^{21}$ The results using the dependent variables in log changes give less weight to large changes in dollar spending and are economically and statistically similar to the other results. While the goal of the paper is to measure the mean effect, alternative approaches and assumptions speak to robustness. For food and strictly nondurable goods, using median regressions or winsorizing the dependent variable generally leads to similar results. For total expenditures, and to a lesser extent nondurable goods, the resulting coefficients are generally smaller than in Table 4, though still statistically and economically significant. For example, the results from 2SLS regressions with the dependent variable winsorized at the 1st and 99th percentile are: $0.019(0.026), 0.088(0.048), 0.144(0.060), 0.421(0.187)$ across the four expenditure aggregates. For median regressions, the corresponding point estimates are similar and
} 


\section{B. Identification using variation among households that receive ESPs at some time}

The results in Table 4 identify the effect of receipt on spending by comparing the behavior of households that received payments at different times to the behavior of households that did not receive payments during those times. Since some households did not receive any payment, in any period, the results still use some information that comes from comparing households that received payments to households that never received payments. We now investigate the role of this variation using a number of different approaches, for brevity focusing on strictly nondurable expenditures, nondurable expenditures, and total expenditures.

First, in Table 5, Panel A adds to equation (1) an indicator for households that received a payment in any reference quarter, $I\left(\sum_{\text {household }} E S P>0\right)$, which allows the expenditure growth of payment recipients to differ on average from that of non-recipients. In this case, the main regressor $I\left(E S P_{t+1}>0\right)$ captures only higher-frequency variation in the timing of payment receipt -- receipt in quarter $t+1$ in particular -- conditional on receipt in some quarter. As reported in Table 5, the estimated coefficients on $I\left(\sum_{\text {household }} E S P>0\right)$ are statistically insignificant. Hence, apart from the effect of the payment, the expenditure growth of payment recipients is on average similar to that of non-recipients over the quarters in the sample period around the payments. Moreover, the estimated coefficients for the effect of the payment $\left(E S P_{t+1}\right.$ and $\left.I\left(E S P_{t+1}>0\right)\right)$ are rather similar to those in Table 4. Hence the results in Table 4 are not driven by differences in expenditure growth between payment recipients and non-recipients over the sample period. That is, controlling for whether a household ever received a payment, spending significantly increases in the particular quarter of payment receipt.

Our second approach is more stringent. Panel B of Table 5 excludes from the sample all households that did not report a payment in any of their reference quarters. The advantage of this approach is that, when we do not use variation in ESP amount, the response of spending is identified using only the variation in the timing of payment receipt conditional on receipt. That

standard errors smaller except for total expenditures for which the estimated effect is $0.215(0.052)$. The smaller point estimates for total expenditures (and to a lesser extent, broadly-defined nondurable goods) are consistent with iatrogenic bias in these alternative specifications, since the distribution of expenditure changes (dC) has much more of its mass in the tails for total expenditures than for nondurable expenditures. In particular, below we find that much of the response in durable spending is in the purchase of cars. If the ESPs cause car purchases, then by deemphasizing these "outliers," one obviously biases down the estimates of the average spending caused by the ESP. Weighting the sample leads to very similar results as in Table 4, for all four expenditure aggregates. For example, the results from weighted 2SLS regressions are: 0.012 (0.033), $0.078(0.060), 0.140(0.071)$, and $0.500(0.221)$, respectively. 
is, identification comes from comparing the spending of households that received payments in a given period to the spending of households that also received payments but in other periods. The disadvantage of this approach is that it leads to a reduction in power due to the resulting decline in sample size and effective variation. Nonetheless, the results are broadly consistent with the previous results (especially when considering the confidence intervals). While as expected the standard errors increase, the point estimates are also somewhat larger than before, and so the results are all statistically significant.

Finally, we focus on the randomized variation in the timing of ESP receipt by dropping all households that received late stimulus payments, after the main period of their (randomized) disbursement. Although the timing of late payments is not necessarily endogenous, it is not randomized. The vast majority of households that received late ESPs did so due to filing late tax returns for tax-year 2007, although as seen in Figure 2, there also seem to be some lags in reporting (or in noticing) the payments in the CE survey. We follow JPS and allow one month's "grace period" in excluding late ESPs, so that we consider a mailed payment to be late if it is reported received after August, and an electronic payment (or any payment with missing data on the method of disbursement) to be late if it is reported received after June.

Table 5 Panel $\mathrm{C}$ shows that the results remain statistically and economically significant. In the final set of columns using 2SLS, on average nondurable expenditures increased by $31 \%$ of the payment in the quarter of receipt, and total expenditures increased by $91 \%$ of the payment. Given that this approach has sufficient power to identify the key parameter of interest, we focus on this sample as our main sample for the balance of the paper.

As another robustness check, Figure 2 compares histograms of the distribution of changes in expenditure for observations during which an ESP is received versus observations during which an ESP is not received. The figure focuses on the sample of on-time recipients and the time period during which the ESPs were being distributed (i.e., when the $t+1$ interview occurs between June 2008 and October 2008, with the corresponding expenditure reference periods covering the preceding three months). As shown, there is a larger share of recipients than nonrecipients in most ranges of increases in spending, and a larger share of non-recipients than recipients in most ranges of decreases in spending. (Each cell represents a \$300 range in Panel A, and a $\$ 600$ range in Panel B, so these differences are economically significant). While these 
histograms do not control for any covariates, they support our main findings non-parametrically in the raw data and show that outliers are not driving the main findings. ${ }^{22}$

In sum, even when limiting the variation to the timing of ESP receipt conditional on (non-late) receipt, the results imply that the receipt of the ESPs had a significant effect on household spending. By contrast, in JPS, analogously limiting the sample to non-late rebate recipients leads to a larger reduction in precision and a loss of statistical significance.

\section{Heterogeneity in treatment effect by method of disbursement}

One novel feature of the 2008 ESP program was the use of electronic funds transfers in addition to mailed checks. About $40 \%$ of the CE households received their payments via EFTs, and the use of EFTs is likely to increase in the future. This subsection first asks whether the method of disbursement affects the estimated spending impact of the ESPs. Second, since the method of disbursement is not randomly assigned and affects the time of receipt, one can think of the ESP program as providing two natural experiments within distinct samples. Accordingly, we proceed to investigate whether we can identify the causal effect of payment receipt from only the difference in arrival times within each method of disbursement.

We begin by estimating the separate response of spending to EFTs and to paper checks, using the analogues of $E S P$ and $I(E S P>0)$ for payments received by check and by EFT. We start with the entire sample of households, including non-recipients, because there is limited temporal variation within ESPs received by EFT. ${ }^{23}$ As shown in Panel A of Table 6, the pattern of estimated coefficients is generally similar across the two disbursement methods, across all the columns. While the point estimates are somewhat larger for the EFTs, they are not statistically different. Next, Panel B uses only the variation within the households that receive only on-time ESPs. The results are similar to those in Panel A in that the estimated coefficients are generally similar (and not statistically significantly different) across the two disbursement methods, though now the point estimates are generally somewhat larger for the mailed checks. Not surprisingly, since the EFTs were disbursed over just a few weeks, using just timing variation leads to relatively less power for estimating the effect of EFT receipt, especially for the noisier total expenditure category. Also, the smaller number of ESPs used to identify the effects of a mailed

\footnotetext{
${ }^{22}$ The analogous histograms are very similar for the sample in Table 4.

${ }^{23}$ A few observations have missing values for the method-of-disbursement question, and so are dropped from the sample.
} 
ESP also raise its standard errors as well. In sum, these results provide little evidence that the method of disbursement significantly affected the average response of spending.

We now turn to the question of whether we can identify the spending effect using only the randomized variation in spending within households that receive only on-time ESPs by check and within households that receive only on-time ESPs by EFT. This approach allows for the selection into each group to be non-random. For example, households receiving EFTs have somewhat higher income on average than households receiving paper checks, and might also be different in other, hard-to-observe ways (e.g., perhaps they are more technologically savvy).

As already discussed, Panels A and B provide some evidence that the spending effect does not differ by method of disbursement. The coefficients in panel B in particular are identified from variation within each group. Importantly, for ESPs received by mail, which provide more temporal variation, the results are statistically significant and broadly similar to the average response in the final panel of Table 5. That is, even separately controlling for receipt of EFTs, using the random variation in the timing of the mailed checks still yields a significant response of spending to the mailed checks.

These results still impose common month dummies and common demographic effects (age and changes in family size) across EFT and mailed-check recipients. Also, to gauge the impact of the stimulus program, we want to estimate the average response to the stimulus payments. Accordingly, as an extension, Panel $\mathrm{C}$ of Table 6 presents estimates from a pooled regression that allows for separate time dummies and demographic effects across three groups of households: a) households that received only paper checks; b) households that received only EFTs; c) households that received both paper checks and EFTs. ${ }^{24}$ The resulting coefficient measures the average spending effect of the receipt of an ESP independent of its method of disbursement, but allowing for households to be distributed across the disbursement methods in a way that is potentially correlated with their spending dynamics due to other factors. While slightly smaller and less statistically significant, the estimates in Panel C remain broadly similar to the estimates in Panel C of Table 5, even though they are driven only by the randomized

\footnotetext{
${ }^{24}$ About 2 percent of households received both EFTs and paper checks. Across all the columns in Panel C, the coefficients on the time dummies (jointly) and the demographic variables (jointly) never significantly vary across the two main groups of households, those who received only EFTs and those who received only mailed checks. These coefficients are sometimes significantly different only for the few households who received both EFTs and paper checks, relative to the two main groups.
} 
variation in timing within each group (primarily paper checks, since the EFTs have limited timing variation).

In sum, our findings remain broadly consistent across specifications that use different forms of variation. Of course, using different variation sometimes induces changes in the point estimates across specifications, especially for total expenditures, but not significantly so relative to the corresponding confidence intervals.

\section{The Longer-Run Response of Expenditure}

To investigate the longer-run effect of the stimulus payments, we add the first lag of the payment variable, $E S P_{t}$, as an additional regressor in equation (1). We continue to focus on the sample of households that only receive ESPs on time (as in Panel C of Table 5).

As shown in Table 7, the presence of the lagged variable does not much alter our previous conclusions about the short-run impact of the payment, although the coefficients on $E S P_{t+1}$ are slightly smaller than the corresponding results in Panel C of Table 5. Moreover, the receipt of a payment causes a change in spending one quarter later (i.e., from the three-month period of receipt to the next three-month period) that uniformly is negative but smaller in absolute magnitude than the contemporaneous change. Since the net effect of the payment on the level of spending in the later quarter is given by the sum of the coefficients on $\operatorname{ESP}_{t}$ and $E S P_{t+1}$, this implies that, after increasing in the three-month period of payment receipt, spending remains high, though less high, in the subsequent three-month period.

These lagged spending effects are, however, estimated with less precision than the contemporaneous effects. For example, in the second-to-last column, for nondurable expenditures using 2SLS, nondurable expenditures rise by $25.4 \%$ of the payment in the quarter of receipt. The expenditure change in the next quarter is $-9.7 \%$, so that nondurable expenditures in the second three-month period are still higher on net than before payment receipt by $25.4 \%$ $9.7 \% \approx 15.6 \%$ of the payment (penultimate row of results). The cumulative change in nondurable expenditures over both three-month periods is then estimated to be $25.4 \%+15.6 \%=41.0 \%$ of the payment (bottom row). However, neither the 16\% change in the second period nor the $41 \%$ cumulative change is statistically significant. The second-period and cumulative changes are also insignificant in the other columns that use 2SLS. However, in the first triplet of columns, using variation in the amount of the ESP increases statistical power, so that we find statistically 
significant effects on spending in the second period for strictly nondurable goods, and on cumulative spending for both strictly nondurable and nondurable expenditure. ${ }^{25}$

In sum, the point estimates suggest some ongoing though decaying spending response to the ESPs in the subsequent quarter after receipt, which counts against an immediate reversal of spending, although we are unable to rule out longer-term reversals. ${ }^{26}$ However, this lagged response cannot be estimated with precision, even on average over the sample period. Hence, in the subsequent extensions in which we estimate spending effects on subsamples of households and goods, which reduces statistical power, we focus on the more precisely estimated short-run response.

\section{Heterogeneity in Responses across Households}

This section and the next section analyze heterogeneity in the response to the stimulus payment, across different types of households and different subcategories of consumption expenditures, respectively. This analysis provides some evidence about why households' expenditures respond to the payments. For brevity, we report results from the 2SLS specification, instrumenting the payment ESP (and any interaction terms) with the corresponding indicator variables for payment receipt $I(E S P>0)$ (and their interactions, along with the other independent variables), for the sample of households receiving only non-late payments.

The presence of liquidity constraints is a leading explanation for why household spending might increase in response to a previously announced increase in income. To investigate this explanation, we test whether households that were relatively likely to be constrained were more likely to increase their spending upon the arrival of a payment. ${ }^{27}$ Constrained households may be unable or unwilling to increase their spending prior to the payment arrival. On the other hand, unconstrained households (e.g., high wealth or high income

\footnotetext{
${ }^{25}$ The coefficients are generally slightly smaller and the statistical significance slightly lower in the sample comprised of all households. If one adds a second lag of the ESP regressor to equation (1), the resulting estimated levels of spending in the third period are again statistically insignificant. For non-durables the point estimates are near zero. For durables, the point estimates suggest an increase in spending from the second period after receipt to the third, and as a result an even larger estimated cumulative spending effect, but these estimates have even greater statistical uncertainty than those reported in Table 7.

${ }^{26}$ To be clear, our key variation -- variation in timing of receipt -- does not involve (almost) any variation in individuals' budget constraints, so all measured effects are about changes in the timing of a household's expenditures rather than its total expenditures (although these effects may help us infer the total effect of the policy). ${ }^{27}$ This constraint could reflect a hard constraint as studied in Zeldes (1989), or larger interest rates for borrowing than for saving (e.g. Davis, Kubler, and Willen (2006)), or a cost for accessing illiquid wealth (e.g. Angeletos, Laibson, Repetto, Tobacman, and Weinberg (2001) and Kaplan and Violante (2011)).
} 
households) may find the costs of not smoothing consumption across the arrival of the payment to be small. ${ }^{28}$

Expanding equation (1), we interact the intercept and $E S P_{t+l}$ variable with indicator variables (Low and High) based on various household characteristics (all from households' first $\mathrm{CE}$ expenditure interview to minimize any endogeneity). We use three different proxy variables to identify households that may be disproportionately likely to be liquidity constrained: age, income (family income before taxes), and liquid assets (the sum of balances in checking and saving accounts). While liquid assets is arguably the most directly relevant of these variables for identifying liquidity constraints, it is the least well measured and the most often missing in the CE data, so we start with the other two variables. ${ }^{29}$ For each variable, we split households into three groups (Low, High, and the intermediate baseline group), with the cutoffs between groups chosen to include about a third of the payment recipients in each group.

Table 8 begins by testing whether the propensity to spend upon receipt of an ESP differs by age. Because young households typically have low liquid wealth and high income growth, they are disproportionately likely to be liquidity constrained (e.g., Jappelli, 1990; Jappelli et. al., 1998). ${ }^{30}$ In the first set of columns in the table, Low refers to young households (40 years old or younger) and High refers to older households (older than 58), and the coefficients on the interaction terms with these variables represent differences relative to the households in the baseline, middle-age group. As reported, the point estimates for the interaction terms suggest that young households spent relatively less of the payment and old households spent relatively more. However these differences, while economically large, are not statistically significant. Nonetheless, in absolute terms the spending by old households (see bottom panel for the interacted groups) and by the middle-age households (main panel for the baseline group) are both statistically and economically significant.

The second set of columns in Table 8 tests for differences in spending across income groups. The point estimates suggest that low-income households spent a much larger fraction of their payment on total expenditures relative to the typical (baseline middle-income) household.

\footnotetext{
${ }^{28}$ See Caballero (1995), Parker (1999), Matejka and Sims (2010), and Reis (2006).

${ }^{29}$ The CE survey does not include the direct measures of borrowing and credit constraints used by Jappelli (1990) and Jappelli et. al. (1998), or Agarwal, Liu, and Souleles (2007).

${ }^{30}$ There is also evidence that older households increase their spending on receiving their (predictable) pension checks (Wilcox, 1989; and Stephens, 2003). Outside the null LCPIH hypothesis of $\beta_{2}=0$, older households might also spend relatively more because they have shorter time horizons on average.
} 
In absolute terms for total expenditures, of the three groups, only the response for the lowincome households is statistically significant. The response is also economically significant, averaging about $125 \%$ of the payment. ${ }^{31}$ However, while suggestive of possible role for liquidity constraints, the difference between this result and that for the baseline group, although economically large at about $70 \%$ of the ESP, is not statistically significant.

The last set of columns in Table 8 tests for differences by liquid asset holdings. The point estimates suggest little spending by low-asset households, but the associated confidence interval is quite large, and none of the differences (although large in point estimate) are statistically significant. The total amounts of spending in absolute terms are insignificant for all three groups, for both nondurable expenditures and total expenditures.

Why do we find such weak results and smaller spending responses among low wealth households? First, the simplest possibility is sampling error. Both smaller sample sizes due to missing asset values and measurement error in the available asset values decrease the precision of the estimates. Roughly half of the data on liquid assets is missing. Further such attrition might not be random, and might be correlated with the treatment effects. Second, use of any proxy variable to split samples leads to misclassification error. Japelli, Pischke, and Souleles (1998) uses more direct information on whether a household is liquidity constrained (e.g., whether the household has been turned down for loans), information which is not available in the CE Survey. That paper estimates switching repressions that explicitly take into account the uncertainty in identifying constrained households, and finds that sample splits based on liquid assets as a proxy for constrained households misclassify some unconstrained households as constrained and some constrained households as unconstrained. Such misclassification tends to attenuate the estimated difference between the groups. ${ }^{32}$ Finally, households might have expected the 2008 recession to last longer than other recessions analyzed in prior literature. If constrained households expect their constraints to bind for a year or two after receiving a payment, rather than for just a few months, under the LCPIH the magnitude of their short-term response to the payment would be smaller.

\footnotetext{
${ }^{31}$ It is not inconsistent for the average spending response to be larger in magnitude than the average payment, even putting aside the confidence intervals for the former, if enough households buy large durables like autos in response to receiving a payment, as found and discussed in the next section.

${ }^{32}$ Misra and Surico (2011) find consistent results using the JPS data.
} 
Another key characteristic of the recent recession was the large decline in housing wealth and the reduced ability to borrow against home equity. To examine the potential implications for the response to the ESPs, Table 9 presents estimates of the spending responses according to housing status. The baseline group is renters ( $23 \%$ of the sample), and the two interacted groups are homeowners with a mortgage $(50 \%)$ and homeowners without a mortgage $(27 \%)$. The point estimates suggest much larger spending responses by both groups of homeowners relative to renters, though the differences are not statistically significant. In absolute terms, homeowners have large and significant responses for all three expenditure categories, whereas the response of renters is smaller and insignificant. As an extension, combining homeowners into one group, the estimated spending responses for total expenditures are $1.051(0.351)$ for homeowners and 0.434 (0.454) for renters, and these estimates are statistically significantly different at the 10 percent level. $^{33}$

\section{Differences in Responses across Types of Expenditure}

Turning to differences across types of expenditures, each column in Table 10 reports the estimated change in spending for each subcategory of expenditures within the broad measure of nondurable expenditures (a complete decomposition). The columns also report, in the bottom panel, the share of the estimated overall increase in nondurable expenditures due to the ESPs that is accounted for by each of the subcategories, and for benchmarking, the average share of each subcategory in nondurable expenditures. Of course, comparisons of different subsets of nondurable expenditure must be interpreted cautiously because of potential non-separabilities across goods.

Further, note that in general the results are statistically weak, with only the estimated coefficient for utilities and household operations being statistically significant. This response is roughly in proportion to the share of this subcategory in nondurable expenditures. As for the other categories, the point estimates suggest a disproportionately large response in alcohol, personal care (and miscellaneous items), tobacco, and apparel, though these responses are

\footnotetext{
${ }^{33}$ The results for homeowners do not simply reflect the preceding results for older households. E.g., if one drops from the sample the households older than 65 , the coefficients for nondurable expenditure remain very similar to those reported in Table 9, for all three groups of homeowner status. The coefficients for total expenditure remain very similar for renters and homeowners with mortgages. While the coefficient for total expenditure loses significance for homeowners without mortgages, presumably in part due to the reduced sample of such homeowners, it remains large in magnitude; and as in the table, the coefficient for nondurable expenditure remains significant and is largest for homeowners without mortgages, compared to the other two groups.
} 
nonetheless statistically insignificant. For such narrow subcategories of expenditures there is much more variability in the dependent variable that is unrelated to the payment regressor. Our previous results, by summing the subcategories into broader aggregates of nondurable expenditures, averaged out much of this unrelated variability (such as, for example, whether a trip to the supermarket happened to fall just inside or outside the expenditure reference-period).

Panel A of Table 11 provides the analogous decomposition of the response of the durable goods and services part of total expenditures (i.e., the part of total expenditures not in the nondurable expenditures category). While there are sizable responses on average in housing (which includes shelter and furniture/appliances) and entertainment (which includes TVs and other electronic equipment), these responses are statistically insignificant and not large relative to their category share in durable goods. The bulk of the response in durables comes in transportation, spending on which increases by $53 \%$ of the payments on average, a statistically and economically significant amount. This response is also large relative to the average share of transportation in durable expenditures. Panel B in turn decomposes the response of the different subcategories of transportation. According to the point estimates, the transportation response is largely driven by purchases of vehicles, primarily new vehicles. These results imply that auto purchases, although weakening during the recession, would have been even weaker in the absence of the payments.

In sum, receipt of a stimulus payment increased the probability of purchasing a vehicle by enough to imply a large average response of total expenditures to the receipt of a payment.

Keeping in mind the degree of statistical significance, our finding of a large spending response on new cars is suggestive of an important role for liquidity constraints. The ESPs may have provided otherwise unavailable down payments for debt-financed purchases of cars. In this case, whether this spending on autos would be reversed in the short term would depend on whether the EPSs caused all households to on average buy a car a few months sooner, leading to no short-term decline in aggregate demand, or whether those whose ESPs did not cause them to purchase a car immediately instead spent their ESPs on other items and were constrained and unable to purchase cars a few months later, leading to a reversal in demand.

In contrast, a back-of-the-envelope calculation suggests that models of inattention seem unlikely to explain the results for autos. Under inattention, broadly speaking, some households can be surprised by their receipt of an ESP. To illustrate the implications for spending, if such 
households spend about ten percent of their expenditures on cars on average (over time and across households), then an increase in lifetime resources from an ESP would lead to an increase in lifetime consumption of car services of about ten percent of the ESP. If cars were infinitely-lived, then this would suggest an average increase in spending on cars of ten percent of the ESP, a number economically (though not statistically) much lower than we find. ${ }^{34}$

\section{Conclusion}

We find that on average households spent about $12-30 \%$ of their stimulus payments, depending on the specification, on (CE-defined) nondurable expenditures during the three-month period in which the payments were received. This response is larger than implied by the LCPIH or Ricardian equivalence. We also find a significant effect on the purchase of durable goods, primarily the purchase of new vehicles, bringing the average response of total consumption expenditures to about $50-90 \%$ of the payments in the quarter of receipt. These results are statistically and economically significant. They remain broadly consistent and significant across specifications that use different forms of variation. Indeed, the point estimates are at the high end of these ranges in specifications that focus most directly on the randomized timing of ESP receipt.

For nondurable expenditures, the estimated spending response to the 2008 ESPs is generally only slightly smaller in magnitude (and not significantly different) than the response to the 2001 tax rebates. This difference might partly reflect the more transitory nature of the 2008 tax cut. However, the composition of spending is different than in 2001, so that the estimated spending effect on total expenditures is larger than that in 2001 due to a larger role for durables in 2008. This difference might partly reflect the larger size of the payments in 2008, or differences in macroeconomic situation (e.g., the doubling in the price of oil might have made more households willing to use the rebate as a down-payment to purchase a more fuel-efficient car). Durables aside, the overall pattern of results is generally similar in 2001 and 2008.

We also find some evidence of an ongoing though smaller response in the subsequent three-month period after ESP receipt, but this response cannot be estimated with precision.

\footnotetext{
${ }^{34}$ Since cars are finite-lived, the increase in spending should be even less than $10 \%$. Incorporating adjustment costs would further reduce the short-term response.
} 
These estimates suggest a significant macroeconomic effect of the 2008 ESPs on consumer demand. To give a sense of the effect, we calculate alternative paths for aggregate consumption that subtract the direct spending caused by the ESPs, as implied by our point estimates and the monthly pattern of distribution of the ESPs. In Figure 3, the (blue) solid line shows the National Income and Product Accounts measure of actual total aggregate PCE from the third quarter of 2007 to the second quarter of 2009. The dashed lines show this series less estimates of the direct spending effect of the ESP program from different specifications used in the paper. ${ }^{35}$ In all cases the implied effects of the ESPs are economically significant. Quantitatively, our preferred point estimates for total expenditures from Tables 4 and 5 imply that the ESPs increased PCE by about 1.3 to 2.3 percent in 2008Q2 and 0.6 to 1.0 percent in 2008Q3 (at annual rates). Of course, this accounting exercise does not include any potential effects of resource constraints and multiplier effects, but instead simply reveals the magnitude of the direct aggregate demand effect relative to total PCE.

Regarding the implementation of new method of delivering tax cuts, the estimated responses do not significantly differ across paper checks and electronic transfers.

Across households, the responses are largest for older and low-income households, groups which have substantial and statistically significant spending responses. According to the point estimates, the responses are largest for high-asset households but this spending response is not statistically significantly different from zero, and more generally all of the asset results suffer from a lack of statistical power. Also, homeowners are estimated to have higher spending propensities than renters.

\footnotetext{
${ }^{35}$ Thus the dashed lines end after the period over which our results are estimated.
} 


\section{Appendix A: A notification letter for an ESP by electric funds transfer}

Department of the Treasury Diternal Revenue Service

Andover, MA 05501-0025

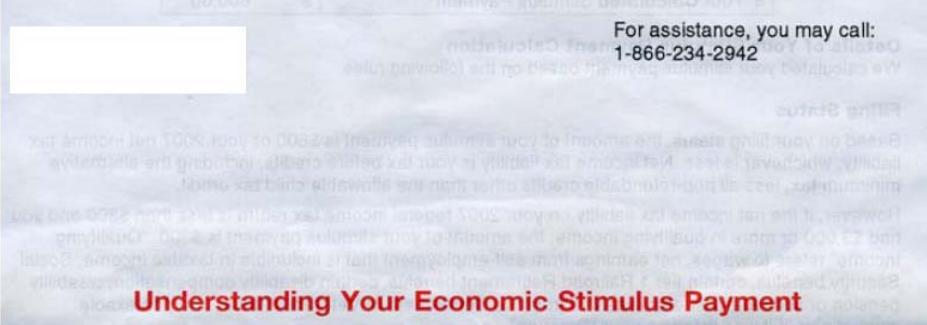

Please keep a copy of this notice for your records.

Dear Taxpayer:

\section{Your Economic Stimulus Payment}

You are entitled to an economic stimulus payment of $\$ 600.00$ as provided by the Economic Stimulus Act of 2008. You can expect your payment by 5/9/08. If you do not receive it within six weeks of this notice, please contact us at the number shown above. You will not be required to report the amount of your stimulus payment as taxable income on your 2008 federal income tax return. If you receive any federal benefits or federally financed benefits, those benefits generally will not be affected by any stimulus payment you receive.

What You Need To Do

You do not need to do anything. If you received a refund on your 2007 federal income tax return and had it directly deposited into a bank account, we will directly deposit your stimulus payment into the same bank account. If not, your stimulus payment check will be mailed to you. If your tax refund was directly deposited into a refund anticipation loan account, your stimulus payment check will be mailed to you.

How We Calculated Your Payment

Your payment is based on information you submitted on your 2007 federal income tax return such as your filing status, the number of qualifying children, and your net income tax liability. The next page shows a detailed explanation of how we calculated your stimulus payment.

Note: You will not be required to report the amount of your stimulus payment as taxable income on your 2008 federal income tax return.

For general information, tax forms, and publications or to view "Where is My Stimulus Payment", visit www.irs.gov

monwirsogov

Catalog Number 51256m Notice 1378 (5-2008)

\begin{tabular}{|c|c|c|c|}
\hline & \multicolumn{2}{|l|}{\begin{tabular}{|c|} 
Your Stimulus Payment Calculation \\
\end{tabular}} & \\
\hline & + Filing Status & 600.00 & \\
\hline & + For qualifying children & 0.00 & \\
\hline & - Reduction for Adjusted Gross Income Limitation & 0.00 & \\
\hline & $=$ Your Calculated Stimulus Payment & 600.00 & \\
\hline \multicolumn{4}{|c|}{$\begin{array}{l}\text { Details of Your Stimulus Payment Calculation } \\
\text { We calculated your stimulus payment based on the following rules. }\end{array}$} \\
\hline \multicolumn{4}{|c|}{ 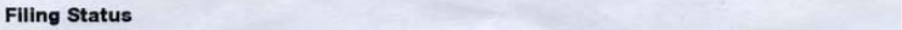 } \\
\hline \multicolumn{4}{|c|}{$\begin{array}{l}\text { Based on your filing status, the amount of your stimulus payment is } \$ 600 \text { or your } 2007 \text { net income tax } \\
\text { liability, whichever is less. Net income tax liability is your tax before credits, including the alternative } \\
\text { minimum tax, less all non-refundable credits other than the allowable child tax credit. }\end{array}$} \\
\hline \multicolumn{4}{|c|}{$\begin{array}{l}\text { However, if the net income tax liability on your } 2007 \text { federal income tax return is less than } \$ 300 \text { and you } \\
\text { had } \$ 3,000 \text { or more in qualifying income, the amount of your stimulus payment is } \$ 300 \text {. "Qualifying } \\
\text { Income" refers to wages, net earnings from self-employment that is includible in taxable income, Social } \\
\text { Security benefits, certain tier } 1 \text { Railroad Retirement benefits, certain disability compensation, disability } \\
\text { pension or survivors' benefits received from the Department of Veterans Affairs, and nontaxable } \\
\text { combat pay (if it was listed on your tax return). }\end{array}$} \\
\hline \multicolumn{4}{|c|}{ Qualifying Children } \\
\hline \multicolumn{4}{|c|}{$\begin{array}{l}\text { The calculation is based on the number of qualifying children multiplied by } \$ 300 \text {. A child is generally } \\
\text { considered a qualifying child for the calculation of your } 2008 \text { stimulus payment if the child was borm } \\
\text { after December } 31,1990 \text {, and has a valid Social Security Number. The number of qualifying children } \\
\text { shown on your } 2007 \text { federal income tax return was } 0 \text {. }\end{array}$} \\
\hline \multicolumn{4}{|c|}{ Whom You Can Contact With Questions } \\
\hline
\end{tabular}




\section{Appendix B: The 2008 ESP Survey Instrument}

The following questions were asked in all CE interviews in June 2008 - March 2009:

[Earlier this year/Last year] the Federal government approved an economic stimulus package. [Many households will receive a one-time economic stimulus payment, either by check or direct deposit/Previously you or your CU [[consumer unit]] reported receiving one or more economic stimulus payments.] This is also called a tax rebate and is different from a refund on your annual income taxes.

Since the first of the reference month, have you or any members of your CU received a/an additional

10. Tax rebate? [Economic Stimulus Payment]

99. None/No more entries

Who was the rebate for? [enter text]

* Collect each rebate separately and include the name(s) of the recipient(s).

In what month did you receive the rebate? [enter text]

What was the total amount of the rebate? [enter value]

* Probe if the amount is not an expected increment such as $\$ 300, \$ 600, \$ 900, \$ 1,200$, etc

Was the rebate received by - ?

1 . check?

2. direct deposit?

Did you or any members of your CU receive any other tax rebate [economic stimulus payment]?

$\underline{1 . \text { Yes }}$

2. No

If yes, return to "Who was the tax rebate for?" 


\section{Appendix C: The CE Data}

We construct the economic stimulus payment variable ESP from the CE ESP data (Appendix A) in a similar manner to JPS's construction of the 2001 tax rebate variable. The 2008 data require fewer consistency checks and adjustments, however. This is partly because by 2008 the CE survey used CAPI software to input and cross-check respondents' replies.

Moreover, with a few exceptions, each interview records only ESPs received during the months of the interview's reference period. We adjusted the exceptions to bring their payments into the appropriate consumption reference period.

We use the following definitions of the other main variables. Age is the average age of the head and spouse when the household is a married couple, otherwise it is just the age of the head. The number of children is calculated as the number of members of the household younger than 18 .

Following Lusardi (1996), strictly nondurable expenditures include expenditures on food (away from home, at home and alcoholic beverages), utilities (and fuels and public services), household operations, public transportation and gas and motor oil, personal care, tobacco, and miscellaneous goods. Nondurable expenditures (broadly defined) adds spending on apparel goods and services, health care (excluding payments by employers or insurers), and reading materials, following Lusardi (1996) but excluding education. Total expenditure adds spending on education, housing (including furniture and appliances and shelter but excluding utilities and household operations, which are already included in nondurable expenditures), transportation (including vehicle purchases, maintenance, and insurance, but excluding public transportation and gas and motor oil), and entertainment (e.g., including TVs and other electronics, as well as fees).

Turning to the sample, we omit observations missing any of the key data that we use in our regressions. Our sample omits the bottom one percent of nondurable consumption expenditures in levels (after adjusting for family size and allowing for a time trend), since this data implies implausibly small (often negative) consumption expenditures. Finally, we drop household observations that report living in student housing, that report age less than 21 or greater than 85 , that report age changing by more than one or a negative amount between quarters, or that report changes in the number of children or adults greater than three in absolute magnitude. When we split the sample based on income, we drop households flagged as 
incompletely reporting income. When we split based on liquid assets, we drop households if the asset information used in computing initial assets (as the difference between final assets and the change in assets) is topcoded. 


\section{References}

Aaronson, Daniel, Sumit Agarwal, and Eric French, 2008, "The Spending and Debt Response to Minimum Wage Hikes” Federal Reserve Bank of Chicago Working Paper No 2007-23, May. Adams, William, Einav, Liran, and Levin, Jonathan, 2009, “Liquidity Constraints and Imperfect Information in Subprime Lending," American Economic Review, 99(1), March, pp. 49-84.

Agarwal, Sumit, Liu, Chunlin and Souleles, Nicholas S., 2007, "The Response of Consumer Spending and Debt to Tax Rebates - Evidence from Consumer Credit Data," Journal of Political Economy, 115(6), December, pp. 986-1019.

Angeletos, George-Marios, David Laibson, Andrea Repetto, Jeremy Tobacman, and Stephen Weinberg, 2001, "The Hyperbolic Buffer Stock Model: Calibration, Simulation, and Empirical Evaluation,” Journal of Economic Perspectives, 15(3), Summer, 47-68.

Auerbach, Alan J., and Gale, William G., 2009, “Activist Fiscal Policy to Stabilize Economic Activity," working paper, September.

Barrow, Lisa, and McGranahan, Leslie, 2000, "The Effects of Earned Income Credit on the Seasonality of Household Expenditures," National Tax Journal, December, 53, pp. 1211-44. Bertrand, Marianne, and Morse, Adair, 2009, "What do High-Interest Borrowers Do with their Tax Rebate?” American Economic Review (Papers and Proceedings), May.

Broda, Christian, and Parker, Jonathan, 2008, “The Impact of the 2008 Tax Rebates on

Consumer Spending: Preliminary Evidence," working paper, July.

Browning, Martin and Lusardi, Annamaria, 1996, "Household Saving: Micro Theories and Macro Facts," Journal of Economic Literature, 34(4), pp 1797-1855.

Bureau of Labor Statistics, U.S. Department of Labor, 2009, “Consumer Expenditure Survey Results on the 2008 Economic Stimulus Payments (Tax Rebates),” October, (http://www.bls.gov/cex/taxrebate.htm).

Caballero, Ricardo J., 1995, "Near Rationality, Heterogeneity, and Aggregate Consumption,” Journal of Money, Credit, and Banking, February, 27(1), pp. 29-48.

$\mathrm{CCH}, 2008$, “CCH Tax Briefing: Economic Stimulus Package,” February 13.

Chamberlain, Gary, 1984, "Panel Data," in Griliches, Zvi, and Intriligator, Michael D., eds., Handbook of Econometrics, Amsterdam: North-Holland.

Coronado, Julia Lynn, Lupton, Joseph P., and Sheiner, Louise M., 2006, “The Household Spending Response to the 2003 Tax Cut: Evidence from Survey Data," working paper. 
Davis, Steven J., Felix Kubler,and Paul Willen, 2006, "Borrowing Costs and the Demand for Equity over the Life Cycle," Review of Economic Statistics, Vol. 88, No. 2 (May), pp. 348362.

Deaton, Angus, 1992, Understanding Consumption, Oxford: Clarendon Press.

Jappelli, Tullio, 1990, "Who is Credit Constrained in the U.S. Economy?" Quarterly Journal of

Economics, February, 105, pp. 219-234.

Jappelli , Tullio and Luigi Pistaferri, 2010, "The Consumption Response to Income Changes,"

NBER Working Paper 15739, February.

Jappelli, Tullio, Pischke, Jörn-Steffen, and Souleles, Nicholas S., 1998, “Testing for Liquidity

Constraints in Euler Equations with Complementary Data Sources," The Review of

Economics and Statistics, 80, pp. 251-262.

Johnson, David S., Parker, Jonathan A., and Souleles, Nicholas S., 2006, "Household

Expenditure and the Income Tax Rebates of 2001," American Economic Review, 96, pp. 1589-1610.

Johnson, David S., Parker, Jonathan A., and Souleles, Nicholas S., 2009, "The Response of

Consumer Spending to Rebates During an Expansion: Evidence from the 2003 Child Tax Credit," working paper, April.

Kaplan, Greg and Giovanni L. Violante, 2011, “A Model of the Consumption Response to Fiscal Stimulus Payments," NBER Working Paper 17338, August.

Leininger, Lindsey, Helen Levy, and Diane Schanzenbach, 2010. “Consequences of SCHIP

Expansions for Household Well-Being," Forum for Health Economics \& Policy 13(1)

(Frontiers in Health Policy Research).

Lusardi, Annamaria, 1996, "Permanent Income, Current Income, and Consumption: Evidence from Two Panel Data Sets," Journal of Business Economics and Statistics, January, 14(1), pp. 81-90.

Matejka, Filip and Christopher A. Sims, 2010, "Discrete Actions in Information-Constrained Tracking Problems,” Princeton University manuscript.

Mian, Atif and Amir Sufi, 2010, “The Effects of Fiscal Stimulus: Evidence from the 2009 'Cash for Clunkers' Program,” The Quarterly Journal of Economics, 2012.

Misra, Kanishka, and Paolo Surico, 2011, "Heterogeneous Responses and Aggregate Impact of the 2001 Income Tax Rebates”, Manuscript, London Business School, March. 
Parker, Jonathan A., 1999, "The Reaction of Household Consumption to Predictable Changes in Social Security Taxes,” American Economic Review, September, 89(4), pp. 959-973.

Reis, Ricardo, 2006, “Inattentive Consumers,” Journal of Monetary Economics, 53(8), pp. 176180.

Sahm, Claudia R., Shapiro, Matthew D. and Slemrod, Joel B., 2010, "Household Response to the 2008 Tax Rebates: Survey Evidence and Aggregate Implications,” in Tax Policy and The Economy, ed. Jeffrey R. Brown, Cambridge: MIT Press.

Shapiro, Matthew D. and Slemrod, Joel B., 2003a, "Consumer Response to Tax Rebates," American Economic Review, 85, pp. 274-283.

Shapiro, Matthew D., and Slemrod, Joel B., 2003b, "Did the 2001 Tax Rebate Stimulate Spending? Evidence from Taxpayer Surveys," Tax Policy and the Economy, ed. James Poterba, Cambridge: MIT Press.

Shapiro, Matthew W. and Slemrod, Joel B., 2009, "Did the 2008 Tax Rebates Stimulate Spending?” American Economic Review, May, 99(2), pp. 374-79.

Slemrod, Joel B., Christian, Charles, London, Rebecca, and Parker, Jonathan A., 1997, “April 15 Syndrome," Economic Inquiry, October, 35(4), pp. 695-709.

Souleles, Nicholas S., 1999, "The Response of Household Consumption to Income Tax Refunds," American Economic Review, September, 89(4), pp. 947-958.

Souleles, Nicholas S., 2004, "Expectations, Heterogeneous Forecast Errors, and Consumption: Micro Evidence from the Michigan Consumer Sentiment Surveys," Journal of Money, Credit, and Banking, February, 36 (1), pp. 39-72.

Stephens, Melvin, Jr., 2003, “3 ${ }^{\text {rd }}$ of tha Month: Do Social Security Recipients Smooth Consumption Between Checks?" American Economic Review, 93, pp. 406-422.

Department of the Treasury, "Daily Treasury Statement," Washington: GPO, 2008, various issues.

Wilcox, David W., 1989, "Social Security Benefits, Consumption Expenditures, and the Life Cycle Hypothesis," Journal of Political Economy, 97, pp. 288-304.

Zeldes, Stephen P., 1989, "Consumption and Liquidity Constraints: An Empirical Investigation,” Journal of Political Economy, 97, pp. 305-346. 


\section{Table 1: The timing of the economic stimulus payments}

Table 1: The timing of the economic stimulus payments

\begin{tabular}{|c|c|c|c|}
\hline \multicolumn{2}{|c|}{$\begin{array}{l}\text { Panel A: Payments by electronic } \\
\text { funds transfer }\end{array}$} & \multicolumn{2}{|c|}{ Panel B: Payments by paper check } \\
\hline $\begin{array}{c}\text { Last two digits of } \\
\text { taxpayer SSN }\end{array}$ & $\begin{array}{c}\text { Date ESP funds } \\
\text { transferred to } \\
\text { account by }\end{array}$ & $\begin{array}{l}\text { Last two digits of } \\
\text { taxpayer SSN }\end{array}$ & $\begin{array}{l}\text { Date ESP check in } \\
\text { the mail by }\end{array}$ \\
\hline $00-20$ & May 2 & $00-09$ & May 16 \\
\hline $21-75$ & May 9 & $10-18$ & May 23 \\
\hline \multirow[t]{7}{*}{$76-99$} & May 16 & $19-25$ & May 30 \\
\hline & & $26-38$ & June 6 \\
\hline & & $39-51$ & June 13 \\
\hline & & $52-63$ & June 20 \\
\hline & & $64-75$ & June 27 \\
\hline & & $76-87$ & July 4 \\
\hline & & $88-99$ & July 11 \\
\hline
\end{tabular}

Source: Internal Revenue Service (http://www.irs.gov/newsroom/article/0,,id=180247,00.html) 
Table 2: Sample statistics

\begin{tabular}{|c|c|c|c|c|c|c|c|c|}
\hline \multirow[b]{2}{*}{ Variable } & \multicolumn{2}{|c|}{ Full sample } & \multicolumn{2}{|c|}{ On-time recipients } & \multicolumn{2}{|c|}{$\begin{array}{l}\text { Households with only } \\
\text { on-time ESPs by check }\end{array}$} & \multicolumn{2}{|c|}{$\begin{array}{l}\text { Households with only } \\
\text { on-time ESPs by EFT }\end{array}$} \\
\hline & Mean & (std dev) & Mean & (std dev) & Mean & (std dev) & Mean & (std dev) \\
\hline \multicolumn{9}{|l|}{ Expenditures on: } \\
\hline Food & 1,964 & $(1,370)$ & 1,939 & $(1,243)$ & 1,858 & $(1,248)$ & 2,041 & $(1,189)$ \\
\hline Strictly nondurables & 4,397 & $(2,815)$ & 4,384 & $(2,469)$ & 4,178 & $(2,446)$ & 4,647 & $(2,418)$ \\
\hline Nondurables & 5,523 & $(3,559)$ & 5,536 & $(3,107)$ & 5,295 & $(3,122)$ & 5,845 & $(2,993)$ \\
\hline Total & 10,797 & $(8,616)$ & 10,601 & $(7,318)$ & 9,895 & $(7,071)$ & 11,603 & $(7,482)$ \\
\hline \multicolumn{9}{|c|}{ Change in Expenditures on: } \\
\hline Food & -16.4 & $(1,243)$ & -5.8 & $(1,049)$ & -1.3 & $(1,074)$ & -13.0 & $(1,003)$ \\
\hline Strictly nondurables & -27.3 & $(2,162)$ & -13.2 & $(1,893)$ & -12.2 & $(1,868)$ & -20.5 & $(1,918)$ \\
\hline Nondurables & -17.2 & $(2,575)$ & -2.6 & $(2,312)$ & 7.3 & $(2,295)$ & -26.0 & $(2,328)$ \\
\hline Total & -231.1 & $(7,772)$ & -168.3 & $(7,131)$ & -117.8 & $(6,814)$ & -272.0 & $(7,519)$ \\
\hline \multicolumn{9}{|l|}{ Level of: } \\
\hline Number of Adults & 1.9 & $(0.8)$ & 2.0 & $(0.8)$ & 1.9 & $(0.8)$ & 1.9 & $(0.7)$ \\
\hline Number of Children & 0.7 & (1.1) & 0.7 & (1.1) & 0.6 & (1.1) & 0.8 & (1.1) \\
\hline \multicolumn{9}{|l|}{ Change in: } \\
\hline Number of Adults & 0.0 & $(0.23)$ & 0.0 & $(0.22)$ & 0.0 & $(0.22)$ & 0.0 & $(0.21)$ \\
\hline Number of Children & 0.0 & $(0.18)$ & 0.0 & $(0.18)$ & 0.0 & $(0.18)$ & 0.0 & $(0.17)$ \\
\hline Age & 50.0 & $(15.1)$ & 50.0 & $(15.0)$ & 52.2 & $(15.4)$ & 46.7 & (13.8) \\
\hline ESP & 168 & $(424)$ & 260 & $(506)$ & 244 & $(474)$ & 276 & $(542)$ \\
\hline$I(E S P>0)$ & 0.17 & $(0.38)$ & 0.27 & $(0.44)$ & 0.27 & $(0.44)$ & 0.26 & $(0.44)$ \\
\hline$E S P \mid E S P>0(\mathrm{~N}=690)$ & 960 & (520) & 971 & (518) & 899 & (490) & 1082 & (527) \\
\hline Income & 60,031 & $(47,635)$ & 60,020 & $(42,239)$ & 54,265 & $(41,237)$ & 68,488 & $(41,897)$ \\
\hline Liquid Assets & 9,553 & $(20,193)$ & 9,959 & $(20,145)$ & 9,244 & $(19,454)$ & 11,165 & $(21,466)$ \\
\hline
\end{tabular}

Notes: The first two samples correspond to those used in Table 4 and Table 5 Panel C. The final two samples together with households that receive payments both by electronic transfer of funds and by check, comprise the sample used in Table 6 Panels B and C. The samples used to calculate income and liquid assets data include only households with valid information on these variables and so are subsamples of the samples used in these tables. For the income and assets variables, the on-time recipients sample corresponds to the samples used in the final two triplets of columns in Table 8. 


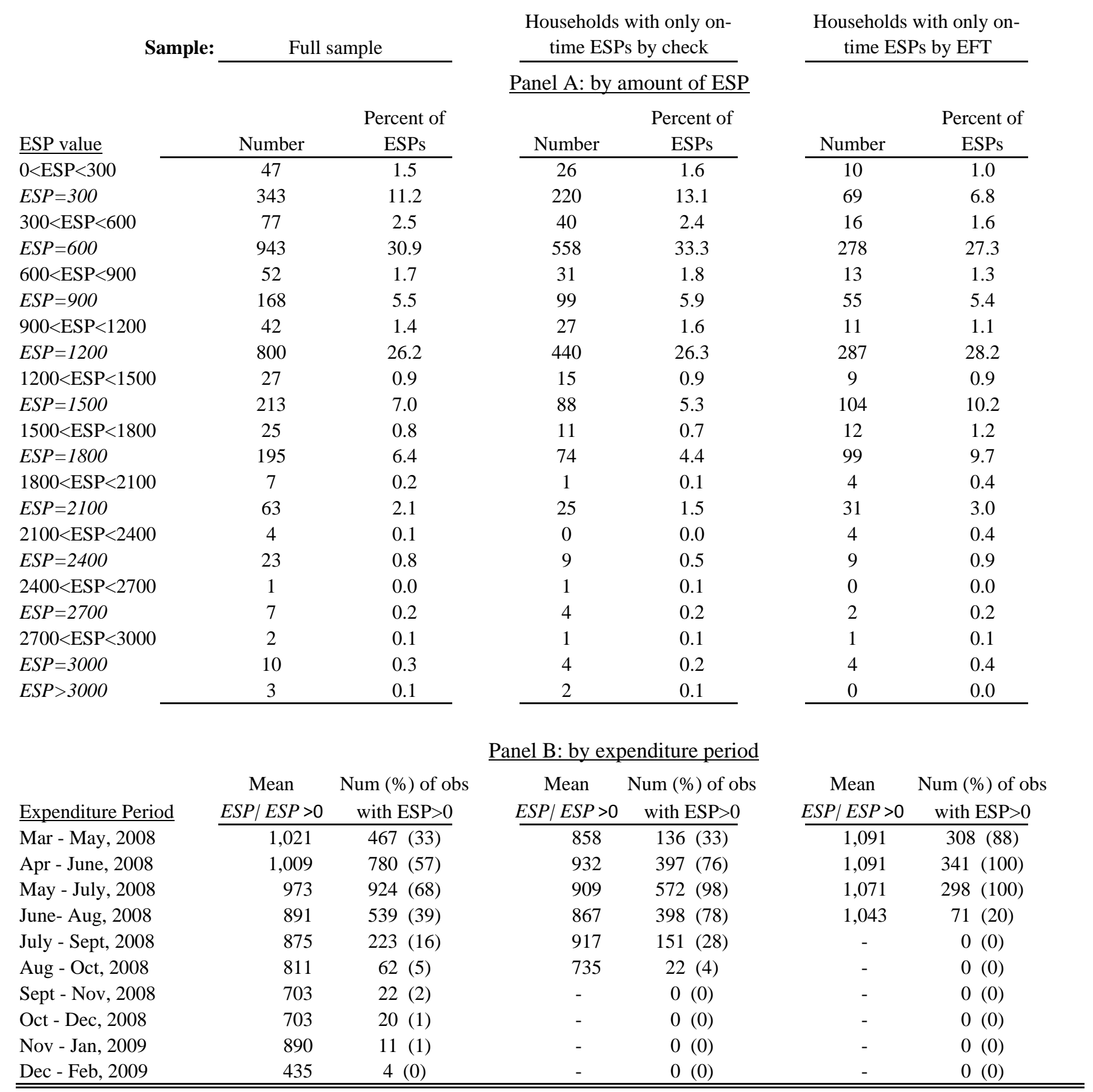

Notes: The first sample corresponds to that used in Table 4. The second and third samples together with households that receive payments both by electronic funds transfer and by check, comprise the sample used in Table 6 Panel C. 
Table 4: The contemporaneous response of expenditures to the ESPs among all households

\begin{tabular}{|c|c|c|c|c|c|c|c|c|c|c|c|c|c|c|c|c|}
\hline \multirow[t]{2}{*}{$\begin{array}{r}\text { Dependent } \\
\text { Variable: }\end{array}$} & \multicolumn{4}{|c|}{ Dollar change in } & \multicolumn{4}{|c|}{ Dollar change in } & \multicolumn{4}{|c|}{ Percent change in } & \multicolumn{4}{|c|}{ Dollar change in } \\
\hline & Food & $\begin{array}{c}\text { Strictly } \\
\text { Non- } \\
\text { durables }\end{array}$ & $\begin{array}{c}\text { Non- } \\
\text { durable } \\
\text { spending }\end{array}$ & $\begin{array}{c}\text { Total } \\
\text { spending }\end{array}$ & Food & $\begin{array}{c}\text { Strictly } \\
\text { Non- } \\
\text { durables }\end{array}$ & $\begin{array}{c}\text { Non- } \\
\text { durable } \\
\text { spending }\end{array}$ & $\begin{array}{c}\text { Total } \\
\text { spending }\end{array}$ & Food & $\begin{array}{c}\text { Strictly } \\
\text { Non- } \\
\text { durables }\end{array}$ & $\begin{array}{c}\text { Non- } \\
\text { durable } \\
\text { spending }\end{array}$ & $\begin{array}{c}\text { Total } \\
\text { spending }\end{array}$ & Food & $\begin{array}{c}\text { Strictly } \\
\text { Non- } \\
\text { durables }\end{array}$ & $\begin{array}{c}\text { Non- } \\
\text { durable } \\
\text { spending }\end{array}$ & $\begin{array}{c}\text { Total } \\
\text { spending }\end{array}$ \\
\hline $\begin{array}{r}\text { Estimation } \\
\text { method: }\end{array}$ & OLS & OLS & OLS & OLS & OLS & OLS & OLS & OLS & OLS & OLS & OLS & OLS & 2SLS & 2SLS & 2SLS & 2SLS \\
\hline$I(E S P)$ & & & & & $\begin{array}{c}10.9 \\
(31.7)\end{array}$ & $\begin{array}{c}74.8 \\
(56.6)\end{array}$ & $\begin{array}{l}121.5 \\
(67.2)\end{array}$ & $\begin{array}{c}494.5 \\
(207.2)\end{array}$ & $\begin{array}{c}0.69 \\
(1.27)\end{array}$ & $\begin{array}{c}1.74 \\
(0.96)\end{array}$ & $\begin{array}{c}2.09 \\
(0.94)\end{array}$ & $\begin{array}{c}3.24 \\
(1.17)\end{array}$ & & & & \\
\hline Age & $\begin{array}{c}0.72 \\
(0.34)\end{array}$ & $\begin{array}{l}-0.23 \\
(0.65)\end{array}$ & $\begin{array}{c}0.96 \\
(0.81)\end{array}$ & $\begin{array}{c}6.56 \\
(2.25)\end{array}$ & $\begin{array}{c}0.70 \\
(0.34)\end{array}$ & $\begin{array}{l}-0.35 \\
(0.65)\end{array}$ & $\begin{array}{c}0.77 \\
(0.81)\end{array}$ & $\begin{array}{c}5.77 \\
(2.24)\end{array}$ & $\begin{array}{c}0.048 \\
-0.010\end{array}$ & $\begin{array}{c}0.009 \\
-0.010\end{array}$ & $\begin{array}{c}0.029 \\
-0.010\end{array}$ & $\begin{array}{c}0.045 \\
-0.010\end{array}$ & $\begin{array}{c}0.71 \\
(0.34)\end{array}$ & $\begin{array}{l}-0.23 \\
(0.65)\end{array}$ & $\begin{array}{c}0.97 \\
(0.81)\end{array}$ & $\begin{array}{c}6.57 \\
(2.26)\end{array}$ \\
\hline $\begin{array}{l}\text { Change in } \\
\text { \# children }\end{array}$ & $\begin{array}{c}89 \\
(48)\end{array}$ & $\begin{array}{l}139 \\
(96)\end{array}$ & $\begin{array}{c}185 \\
(111)\end{array}$ & $\begin{array}{l}-254 \\
(388)\end{array}$ & $\begin{array}{c}89 \\
(48)\end{array}$ & $\begin{array}{l}139 \\
(96)\end{array}$ & $\begin{array}{c}186 \\
(111)\end{array}$ & $\begin{array}{l}-252 \\
(388)\end{array}$ & $\begin{array}{c}4.50 \\
(2.02)\end{array}$ & $\begin{array}{c}3.35 \\
(1.53)\end{array}$ & $\begin{array}{c}3.93 \\
(1.50)\end{array}$ & $\begin{array}{c}1.42 \\
(2.10)\end{array}$ & $\begin{array}{c}89 \\
(48)\end{array}$ & $\begin{array}{l}139 \\
(96)\end{array}$ & $\begin{array}{c}185 \\
(111)\end{array}$ & $\begin{array}{l}-254 \\
(388)\end{array}$ \\
\hline Num of obs & 17,478 & 17,478 & 17,478 & 17,478 & 17,478 & 17,478 & 17,478 & 17,478 & 17,427 & 17,475 & 17,478 & 17,478 & 17,478 & 17,478 & 17,478 & 17,478 \\
\hline
\end{tabular}

Notes: All regressions also include a full set of month dummies, following equation (1). Reported standard errors are adjusted for arbitrary within-household correlations and heteroskedasticity. The coefficients in the third set of columns are multiplied by 100 so as to report a percent change. The last four columns report results from 2 SLS

regressions where the indicator variable for ESP receipt and the other regressors are used as instruments for the amount of the ESP. 
Table 5: The response to the ESPs among households receiving payments

\begin{tabular}{|c|c|c|c|c|c|c|c|c|c|}
\hline \multirow[t]{2}{*}{$\begin{array}{r}\text { Dependent } \\
\text { Variable: }\end{array}$} & \multicolumn{3}{|c|}{ Dollar change in } & \multicolumn{3}{|c|}{ Percent change in } & \multicolumn{3}{|c|}{ Dollar change in } \\
\hline & $\begin{array}{c}\text { Strictly } \\
\text { Non- } \\
\text { durables }\end{array}$ & $\begin{array}{l}\text { Non-durable } \\
\text { spending }\end{array}$ & $\begin{array}{c}\text { Total } \\
\text { spending }\end{array}$ & $\begin{array}{c}\text { Strictly } \\
\text { Non- } \\
\text { durables }\end{array}$ & $\begin{array}{c}\text { Non-durable } \\
\text { spending }\end{array}$ & $\begin{array}{c}\text { Total } \\
\text { spending }\end{array}$ & $\begin{array}{l}\text { Strictly } \\
\text { Non- } \\
\text { durables }\end{array}$ & $\begin{array}{l}\text { Non-durable } \\
\text { spending }\end{array}$ & $\begin{array}{c}\text { Total } \\
\text { spending }\end{array}$ \\
\hline $\begin{array}{r}\text { Estimation } \\
\text { method: }\end{array}$ & OLS & OLS & OLS & OLS & OLS & OLS & 2SLS & 2SLS & 2SLS \\
\hline & & & & Panel A: & Sample of all h & ouseholds & & & \\
\hline ESP & $\begin{array}{c}0.073 \\
(0.050)\end{array}$ & $\begin{array}{c}0.117 \\
(0.060)\end{array}$ & $\begin{array}{c}0.507 \\
(0.196)\end{array}$ & & & & $\begin{array}{c}0.071 \\
(0.068)\end{array}$ & $\begin{array}{c}0.123 \\
(0.081)\end{array}$ & $\begin{array}{c}0.509 \\
(0.253)\end{array}$ \\
\hline$I(E S P)$ & & & & $\begin{array}{c}2.20 \\
(1.09)\end{array}$ & $\begin{array}{c}2.63 \\
(1.07)\end{array}$ & $\begin{array}{c}3.97 \\
(1.34)\end{array}$ & & & \\
\hline$I\left(\Sigma_{\text {household }} E S P_{\mathrm{t}}>0\right)$ & $\begin{array}{c}12.01 \\
(30.74)\end{array}$ & $\begin{array}{c}9.58 \\
(36.07)\end{array}$ & $\begin{array}{c}21.21 \\
(104.00)\end{array}$ & $\begin{array}{l}-0.75 \\
(0.51)\end{array}$ & $\begin{array}{l}-0.88 \\
(0.50)\end{array}$ & $\begin{array}{l}-1.17 \\
(0.63)\end{array}$ & $\begin{array}{c}12.66 \\
(33.03)\end{array}$ & $\begin{array}{c}8.23 \\
(38.79)\end{array}$ & $\begin{array}{c}20.77 \\
(112.18)\end{array}$ \\
\hline Number of obs & 17,478 & 17,478 & 17,478 & 17,475 & 17,478 & 17,478 & 17,478 & 17,478 & 17,478 \\
\hline & & & & I B: Samp & of household & receiving & & & \\
\hline ESP & $\begin{array}{c}0.144 \\
(0.054)\end{array}$ & $\begin{array}{c}0.185 \\
(0.066)\end{array}$ & $\begin{array}{c}0.683 \\
(0.219)\end{array}$ & & & & $\begin{array}{c}0.207 \\
(0.087)\end{array}$ & $\begin{array}{c}0.252 \\
(0.103)\end{array}$ & $\begin{array}{c}0.866 \\
(0.329)\end{array}$ \\
\hline$I(E S P)$ & & & & $\begin{array}{c}3.97 \\
(1.36)\end{array}$ & $\begin{array}{c}3.91 \\
(1.33)\end{array}$ & $\begin{array}{c}5.63 \\
(1.69)\end{array}$ & & & \\
\hline Number of obs & 11,239 & 11,239 & 11,239 & 11,238 & 11,239 & 11,239 & 11,239 & 11,239 & 11,239 \\
\hline & & & Panel C: & mple of $\mathrm{h}$ & useholds recei & ing only on & $\underline{\text { me ESPs }}$ & & \\
\hline ESP & $\begin{array}{c}0.188 \\
(0.058)\end{array}$ & $\begin{array}{c}0.214 \\
(0.070)\end{array}$ & $\begin{array}{c}0.590 \\
(0.217)\end{array}$ & & & & $\begin{array}{c}0.262 \\
(0.092)\end{array}$ & $\begin{array}{c}0.308 \\
(0.112)\end{array}$ & $\begin{array}{c}0.911 \\
(0.342)\end{array}$ \\
\hline$I(E S P)$ & & & & $\begin{array}{c}4.61 \\
(1.53)\end{array}$ & $\begin{array}{c}4.52 \\
(1.50)\end{array}$ & $\begin{array}{c}6.05 \\
(1.89)\end{array}$ & & & \\
\hline Number of obs & 10,488 & 10,488 & 10,488 & 10,487 & 10,488 & 10,488 & 10,488 & 10,488 & 10,488 \\
\hline
\end{tabular}

Notes: All regressions also include the change in the number of adults, the change in the number of children, the age of the household, and a full set of month dummies. Reported standard errors are adjusted for arbitrary within-household correlations and heteroskedasticity. The coefficients in the second triplet of coumns are multiplied by 100 so as to report a percent change. The final triplet of columns report results from 2SLS regressions where the indicator variable for ESP receipt and the other regressors are used as instruments for the amount of the ESP. The variable $I\left(\Sigma_{\text {household }} \operatorname{ESP}_{h}>0\right)$ is an indicator for households that received an ESP in some reference quarter, whereasI $(E S P>0)$ indicates receipt in the contemporaneous quarter $(t+1)$ in particular. 
Table 6: The response to the ESPs by method of disbursement

\begin{tabular}{|c|c|c|c|c|c|c|c|c|c|}
\hline \multirow[t]{2}{*}{$\begin{array}{c}\text { Dependent } \\
\text { Variable: }\end{array}$} & \multicolumn{3}{|c|}{ Dollar change in } & \multicolumn{3}{|c|}{ Percent change in } & \multicolumn{3}{|c|}{ Dollar change in } \\
\hline & $\begin{array}{c}\text { Strictly } \\
\text { Non- } \\
\text { durables }\end{array}$ & $\begin{array}{c}\text { Non- } \\
\text { durable } \\
\text { spending }\end{array}$ & $\begin{array}{c}\text { Total } \\
\text { spending }\end{array}$ & $\begin{array}{l}\text { Strictly } \\
\text { Non- } \\
\text { durables }\end{array}$ & $\begin{array}{c}\text { Non- } \\
\text { durable } \\
\text { spending }\end{array}$ & $\begin{array}{c}\text { Total } \\
\text { spending }\end{array}$ & $\begin{array}{c}\text { Strictly } \\
\text { Non- } \\
\text { durables }\end{array}$ & $\begin{array}{c}\text { Non- } \\
\text { durable } \\
\text { spending }\end{array}$ & $\begin{array}{c}\text { Total } \\
\text { spending }\end{array}$ \\
\hline $\begin{array}{r}\text { Estimation } \\
\text { method: }\end{array}$ & OLS & OLS & OLS & OLS & OLS & OLS & 2SLS & 2SLS & 2SLS \\
\hline & \multicolumn{9}{|c|}{ Panel A: Sample of all households } \\
\hline ESP by Check & $\begin{array}{c}0.104 \\
(0.064)\end{array}$ & $\begin{array}{c}0.141 \\
(0.077)\end{array}$ & $\begin{array}{c}0.473 \\
(0.215)\end{array}$ & & & & $\begin{array}{c}0.060 \\
(0.087)\end{array}$ & $\begin{array}{c}0.112 \\
(0.104)\end{array}$ & $\begin{array}{c}0.333 \\
(0.305)\end{array}$ \\
\hline ESP by EFT & $\begin{array}{c}0.086 \\
(0.066)\end{array}$ & $\begin{array}{c}0.144 \\
(0.081)\end{array}$ & $\begin{array}{c}0.583 \\
(0.305)\end{array}$ & & & & $\begin{array}{c}0.108 \\
(0.082)\end{array}$ & $\begin{array}{c}0.169 \\
(0.097)\end{array}$ & $\begin{array}{c}0.661 \\
(0.332)\end{array}$ \\
\hline I(ESP by check) & & & & $\begin{array}{c}1.92 \\
(1.31)\end{array}$ & $\begin{array}{c}2.19 \\
(1.29)\end{array}$ & $\begin{array}{c}3.59 \\
(1.61)\end{array}$ & & & \\
\hline$I(E S P$ by $E F T)$ & & & & $\begin{array}{c}2.81 \\
(1.44)\end{array}$ & $\begin{array}{c}3.35 \\
(1.41)\end{array}$ & $\begin{array}{c}4.00 \\
(1.83)\end{array}$ & & & \\
\hline \multirow[t]{2}{*}{ Number of obs } & 17,281 & 17,281 & 17,281 & 17,278 & 17,281 & 17,281 & 17,281 & 17,281 & 17,281 \\
\hline & \multicolumn{9}{|c|}{ Panel B: Sample of households receiving only on-time ESPs } \\
\hline ESP by Check & $\begin{array}{c}0.220 \\
(0.072)\end{array}$ & $\begin{array}{c}0.245 \\
(0.086)\end{array}$ & $\begin{array}{c}0.746 \\
(0.235)\end{array}$ & & & & $\begin{array}{c}0.257 \\
(0.110)\end{array}$ & $\begin{array}{c}0.308 \\
(0.133)\end{array}$ & $\begin{array}{c}0.868 \\
(0.379)\end{array}$ \\
\hline ESP by EFT & $\begin{array}{c}0.188 \\
(0.071)\end{array}$ & $\begin{array}{c}0.218 \\
(0.090)\end{array}$ & $\begin{array}{c}0.361 \\
(0.317)\end{array}$ & & & & $\begin{array}{c}0.281 \\
(0.095)\end{array}$ & $\begin{array}{c}0.313 \\
(0.117)\end{array}$ & $\begin{array}{c}0.702 \\
(0.402)\end{array}$ \\
\hline I(ESP by check) & & & & $\begin{array}{c}4.14 \\
(1.67)\end{array}$ & $\begin{array}{c}3.99 \\
(1.63)\end{array}$ & $\begin{array}{c}5.78 \\
(2.03)\end{array}$ & & & \\
\hline$I(E S P$ by $E F T)$ & & & & $\begin{array}{c}5.19 \\
(1.83)\end{array}$ & $\begin{array}{c}4.84 \\
(1.81)\end{array}$ & $\begin{array}{c}4.30 \\
(2.38)\end{array}$ & & & \\
\hline \multirow[t]{2}{*}{ Number of obs } & 10,362 & 10,362 & 10,362 & 10,361 & 10,362 & 10,362 & 10,362 & 10,362 & 10,362 \\
\hline & \multicolumn{9}{|c|}{ Panel C: Households receiving only on-time ESPs, } \\
\hline ESP & $\begin{array}{l}0.187 \\
(0.066)\end{array}$ & $\begin{array}{l}0.211 \\
(0.078)\end{array}$ & $\begin{array}{l}0.529 \\
(0.232)\end{array}$ & & & & $\begin{array}{l}0.240 \\
(0.128)\end{array}$ & $\begin{array}{l}0.262 \\
(0.149)\end{array}$ & $\begin{array}{l}0.784 \\
(0.401)\end{array}$ \\
\hline$I(E S P)$ & & & & $\begin{array}{c}3.96 \\
(1.87)\end{array}$ & $\begin{array}{c}3.63 \\
(1.79)\end{array}$ & $\begin{array}{c}5.48 \\
(2.23)\end{array}$ & & & \\
\hline Number of obs & 10,362 & 10,362 & 10,362 & 10,361 & 10,362 & 10,362 & 10,362 & 10,362 & 10,362 \\
\hline
\end{tabular}

Notes: All regressions also include the change in the number of adults, the change in the number of children, the age of the household, a full set of month dummies, and indicators for: a) receiving only ESPs by check; b) receiving only EFTs; and c) receiving both checks and EFTs. In panels B and C, there are also separate sets of all other control variables for households in categories a), b), and c). Reported standard errors are adjusted for arbitrary withinhousehold correlations and heteroskedasticity. The coefficients in the second triplet of coumns are multiplied by 100 so as to report a percent change. The final triplet of columns reports results from 2SLS regressions where I $(E S P>0)$, its interactions, and the other regressors are used as instruments for ESP and its interactions. 


\begin{tabular}{|c|c|c|c|c|c|c|c|c|c|}
\hline \multirow[t]{2}{*}{$\begin{array}{r}\text { Dependent } \\
\text { Variable: }\end{array}$} & \multicolumn{3}{|c|}{ Dollar change in } & \multicolumn{3}{|c|}{ Percent change in } & \multicolumn{3}{|c|}{ Dollar change in } \\
\hline & $\begin{array}{c}\text { Strictly } \\
\text { Non- } \\
\text { durables }\end{array}$ & $\begin{array}{c}\text { Non- } \\
\text { durable } \\
\text { spending }\end{array}$ & $\begin{array}{c}\text { Total } \\
\text { spending }\end{array}$ & $\begin{array}{l}\text { Strictly } \\
\text { Non- } \\
\text { durables }\end{array}$ & $\begin{array}{c}\text { Non- } \\
\text { durable } \\
\text { spending }\end{array}$ & $\begin{array}{c}\text { Total } \\
\text { spending }\end{array}$ & $\begin{array}{l}\text { Strictly } \\
\text { Non- } \\
\text { durables }\end{array}$ & $\begin{array}{c}\text { Non- } \\
\text { durable } \\
\text { spending }\end{array}$ & $\begin{array}{c}\text { Total } \\
\text { spending }\end{array}$ \\
\hline $\begin{array}{r}\text { Estimation } \\
\text { method: }\end{array}$ & OLS & OLS & OLS & OLS & OLS & OLS & 2SLS & 2SLS & 2SLS \\
\hline$E S P_{t+1}$ or $I\left(E S P_{t+1}\right)$ & $\begin{array}{l}0.186 \\
(0.055)\end{array}$ & $\begin{array}{l}0.201 \\
(0.067)\end{array}$ & $\begin{array}{l}0.517 \\
(0.211)\end{array}$ & $\begin{array}{l}3.58 \\
(1.58)\end{array}$ & $\begin{array}{l}3.92 \\
(1.55)\end{array}$ & $\begin{array}{l}4.96 \\
(1.96)\end{array}$ & $\begin{array}{l}0.219 \\
(0.089)\end{array}$ & $\begin{array}{l}0.254 \\
(0.110)\end{array}$ & $\begin{array}{l}0.757 \\
(0.360)\end{array}$ \\
\hline$E S P_{t}$ or $I\left(E S P_{t}\right)$ & $\begin{array}{l}-0.009 \\
(0.068)\end{array}$ & $\begin{array}{l}-0.054 \\
(0.080)\end{array}$ & $\begin{array}{l}-0.288 \\
(0.214)\end{array}$ & $\begin{array}{l}-2.09 \\
(1.51)\end{array}$ & $\begin{array}{l}-1.23 \\
(1.50)\end{array}$ & $\begin{array}{l}-2.22 \\
(1.92)\end{array}$ & $\begin{array}{l}-0.076 \\
(0.092)\end{array}$ & $\begin{array}{l}-0.097 \\
(0.113)\end{array}$ & $\begin{array}{l}-0.278 \\
(0.330)\end{array}$ \\
\hline $\begin{array}{l}\text { Implied spending effect in } \\
\text { second three-month period }\end{array}$ & $\begin{array}{c}0.177 \\
(0.087)\end{array}$ & $\begin{array}{c}0.146 \\
(0.104)\end{array}$ & $\begin{array}{c}0.230 \\
(0.303)\end{array}$ & NA & NA & NA & $\begin{array}{c}0.143 \\
(0.142)\end{array}$ & $\begin{array}{c}0.156 \\
(0.177)\end{array}$ & $\begin{array}{c}0.479 \\
(0.568)\end{array}$ \\
\hline $\begin{array}{l}\text { Implied cumulative fraction } \\
\text { of rebate spent over both } \\
\text { three-month periods }\end{array}$ & $\begin{array}{c}0.363 \\
(0.128)\end{array}$ & $\begin{array}{c}0.347 \\
(0.155)\end{array}$ & $\begin{array}{c}0.747 \\
(0.477)\end{array}$ & NA & NA & NA & $\begin{array}{c}0.362 \\
(0.218)\end{array}$ & $\begin{array}{l}0.410 \\
(0.273)\end{array}$ & $\begin{array}{l}1.236 \\
(0.892)\end{array}$ \\
\hline Number of observations & 10,488 & 10,488 & 10,488 & 10,487 & 10,488 & 10,488 & 10,488 & 10,488 & 10,488 \\
\hline
\end{tabular}

Notes: All regressions also include the change in the number of adults, the change in the number of children, the age of the household, and a full set of month dummies. The sample includes only households receiving only on-time ESPs. Standard errors are adjusted for arbitrary within-household correlations and heteroskedasticity. The coefficients in the second triplet of columns are multiplied by 100 so as to report a percent change. The final triplet of columns reports results from 2SLS regressions where I(ESP) and the other regressors are used as instruments for ESP. 
Table 8: The propensity to spend across different households

\begin{tabular}{|c|c|c|c|c|c|c|c|c|c|}
\hline \multirow[t]{2}{*}{$\begin{array}{c}\text { Dependent } \\
\text { variable: }\end{array}$} & \multicolumn{3}{|c|}{$\frac{\underline{\text { Panel A }}}{\text { Dollar change in }}$} & \multicolumn{3}{|c|}{$\frac{\underline{\text { Panel B }}}{\text { Dollar change in }}$} & \multicolumn{3}{|c|}{$\frac{\underline{\text { Panel C }}}{\text { Dollar change in }}$} \\
\hline & $\begin{array}{l}\text { Strictly } \\
\text { Non- } \\
\text { durables }\end{array}$ & $\begin{array}{c}\text { Non-durable } \\
\text { spending }\end{array}$ & $\begin{array}{c}\text { Total } \\
\text { spending }\end{array}$ & $\begin{array}{l}\text { Strictly } \\
\text { Non- } \\
\text { durables }\end{array}$ & $\begin{array}{l}\text { Non-durable } \\
\text { spending }\end{array}$ & $\begin{array}{c}\text { Total } \\
\text { spending }\end{array}$ & $\begin{array}{l}\text { Strictly } \\
\text { Non- } \\
\text { durables }\end{array}$ & $\begin{array}{l}\text { Non-durable } \\
\text { spending }\end{array}$ & $\begin{array}{c}\text { Total } \\
\text { spending }\end{array}$ \\
\hline & \multicolumn{3}{|c|}{$\begin{array}{l}\text { Interaction: Age } \\
\text { Low: } \leq 40 \\
\text { High: age }>58\end{array}$} & \multicolumn{3}{|c|}{$\begin{array}{c}\text { Interaction: Income } \\
\text { Low: } \leq 32,000 \\
\text { High: }>74,677\end{array}$} & \multicolumn{3}{|c|}{$\begin{array}{c}\text { Interaction: Liquid Assets } \\
\text { Low: } \leq 500 \\
\text { High: }>7,000\end{array}$} \\
\hline$E S P$ & $\begin{array}{c}0.269 \\
(0.110)\end{array}$ & $\begin{array}{c}0.345 \\
(0.133)\end{array}$ & $\begin{array}{c}0.952 \\
(0.398)\end{array}$ & $\begin{array}{c}0.157 \\
(0.096)\end{array}$ & $\begin{array}{c}0.215 \\
(0.124)\end{array}$ & $\begin{array}{c}0.568 \\
(0.442)\end{array}$ & $\begin{array}{c}0.297 \\
(0.134)\end{array}$ & $\begin{array}{c}0.275 \\
(0.164)\end{array}$ & $\begin{array}{c}0.851 \\
(0.558)\end{array}$ \\
\hline $\begin{array}{c}E S P^{*} L o w \\
\text { (group difference) }\end{array}$ & $\begin{array}{l}-0.103 \\
(0.101)\end{array}$ & $\begin{array}{l}-0.150 \\
(0.124)\end{array}$ & $\begin{array}{l}-0.461 \\
(0.399)\end{array}$ & $\begin{array}{c}0.096 \\
(0.121)\end{array}$ & $\begin{array}{c}0.024 \\
(0.155)\end{array}$ & $\begin{array}{c}0.715 \\
(0.500)\end{array}$ & $\begin{array}{l}-0.181 \\
(0.156)\end{array}$ & $\begin{array}{l}-0.253 \\
(0.184)\end{array}$ & $\begin{array}{l}-0.844 \\
(0.527)\end{array}$ \\
\hline $\begin{array}{l}E S P^{*} H i g h \\
\text { (group difference) }\end{array}$ & $\begin{array}{c}0.100 \\
(0.121)\end{array}$ & $\begin{array}{c}0.044 \\
(0.151)\end{array}$ & $\begin{array}{c}0.414 \\
(0.472)\end{array}$ & $\begin{array}{c}0.026 \\
(0.113)\end{array}$ & $\begin{array}{l}-0.009 \\
(0.139)\end{array}$ & $\begin{array}{c}0.205 \\
(0.466)\end{array}$ & $\begin{array}{l}-0.051 \\
(0.154)\end{array}$ & $\begin{array}{l}-0.075 \\
(0.186)\end{array}$ & $\begin{array}{c}0.083 \\
(0.631)\end{array}$ \\
\hline Number of obs & 10,488 & 10,488 & 10,488 & 8,592 & $\begin{array}{r}\text { 8,592 } \\
\text { ied total spenc }\end{array}$ & $\begin{array}{r}8,592 \\
\text { ig } \\
\end{array}$ & 5,071 & 5,071 & 5,071 \\
\hline Low group & $\begin{array}{c}0.166 \\
(0.092)\end{array}$ & $\begin{array}{c}0.195 \\
(0.114)\end{array}$ & $\begin{array}{c}0.491 \\
(0.394)\end{array}$ & $\begin{array}{c}0.253 \\
(0.137)\end{array}$ & $\begin{array}{c}0.239 \\
(0.180)\end{array}$ & $\begin{array}{c}1.283 \\
(0.564)\end{array}$ & $\begin{array}{c}0.116 \\
(0.173)\end{array}$ & $\begin{array}{c}0.022 \\
(0.205)\end{array}$ & $\begin{array}{c}0.007 \\
(0.566)\end{array}$ \\
\hline High group & $\begin{array}{c}0.369 \\
(0.136)\end{array}$ & $\begin{array}{c}0.389 \\
(0.168)\end{array}$ & $\begin{array}{c}1.366 \\
(0.498)\end{array}$ & $\begin{array}{c}0.183 \\
(0.105)\end{array}$ & $\begin{array}{c}0.206 \\
(0.133)\end{array}$ & $\begin{array}{c}0.773 \\
(0.463)\end{array}$ & $\begin{array}{c}0.246 \\
(0.162)\end{array}$ & $\begin{array}{c}0.200 \\
(0.202)\end{array}$ & $\begin{array}{c}0.934 \\
(0.677)\end{array}$ \\
\hline
\end{tabular}

Notes: All regressions also include separate intercepts for the High and Low groups, the change in the number of adults, the change in the number of children, the age of the household, and a full set of month dummies. The sample includes only households receiving only on-time ESPs. All results are from 2SLS regressions where $I(E S P>0)$ and its interactions, along with the other regressors, are used as instruments for ESP and its interactions. Reported standard errors are adjusted for arbitrary within-household correlations and heteroskedasticity. All sample splits are chosen to include about 1/3 of ESP recipients in each grouping. 


\section{Table 9: The propensity to spend by homeownership status}

\begin{tabular}{|c|c|c|c|}
\hline \multirow[t]{2}{*}{ Dependent variable: } & \multicolumn{3}{|c|}{ Dollar change in } \\
\hline & $\begin{array}{l}\text { Strictly } \\
\text { Non- } \\
\text { durables }\end{array}$ & $\begin{array}{c}\text { Non-durable } \\
\text { spending }\end{array}$ & Total spending \\
\hline & \multicolumn{3}{|c|}{$\begin{array}{c}\text { Baseline group: renters (23\% of sample) } \\
\text { First interaction: owners with mortgages (50\%) } \\
\text { Second interaction: owners without mortgages (27\%) }\end{array}$} \\
\hline$E S P$ & $\begin{array}{c}0.197 \\
(0.128)\end{array}$ & $\begin{array}{c}0.213 \\
(0.153)\end{array}$ & $\begin{array}{c}0.431 \\
(0.455)\end{array}$ \\
\hline $\begin{array}{c}E S P^{*} I(\text { Owned with mortgage) } \\
\text { (group difference) }\end{array}$ & $\begin{array}{c}0.030 \\
(0.110)\end{array}$ & $\begin{array}{c}0.043 \\
(0.131)\end{array}$ & $\begin{array}{c}0.543 \\
(0.394)\end{array}$ \\
\hline $\begin{array}{c}\text { ESP*I(Owned without mortgage) } \\
\text { (group difference) }\end{array}$ & $\begin{array}{c}0.175 \\
(0.133)\end{array}$ & $\begin{array}{c}0.260 \\
(0.169)\end{array}$ & $\begin{array}{c}0.800 \\
(0.514)\end{array}$ \\
\hline \multirow[t]{2}{*}{$N$} & 10,380 & 10,380 & 10,380 \\
\hline & \multicolumn{3}{|c|}{ Implied total spending } \\
\hline $\begin{array}{l}\text { Homeowners with } \\
\text { mortgages }\end{array}$ & $\begin{array}{c}0.227 \\
(0.093)\end{array}$ & $\begin{array}{c}0.256 \\
(0.112)\end{array}$ & $\begin{array}{c}0.974 \\
(0.364)\end{array}$ \\
\hline $\begin{array}{c}\text { Homeowners without } \\
\text { mortgages }\end{array}$ & $\begin{array}{c}0.372 \\
(0.135)\end{array}$ & $\begin{array}{c}0.473 \\
(0.175)\end{array}$ & $\begin{array}{c}1.231 \\
(0.508)\end{array}$ \\
\hline
\end{tabular}

Notes: All regressions also include separate intercepts for owners with mortgages and owners without, the change in the number of adults, the change in the number of children, the age of the household, and a full set of month dummies. The sample includes only households receiving only ontime ESPs, and excludes households that occupy without payment of cash rent or that live in student housing. All results are from 2SLS regressions where $I(E S P>0)$ and its interactions, along with the other regressors, are used as instruments for ESP and its interactions. Reported standard errors are adjusted for arbitrary within-household correlations and heteroskedasticity. 
Table 10: The propensity to spend on subcategories of non-durable expenditures

\begin{tabular}{|c|c|c|c|c|c|c|c|c|c|c|}
\hline \multirow[t]{2}{*}{$\begin{array}{r}\text { Dependent } \\
\text { variable: }\end{array}$} & \multicolumn{3}{|c|}{$\begin{array}{c}\text { Panel A: Food } \\
\text { Dollar change in }\end{array}$} & \multicolumn{4}{|c|}{$\frac{\text { Panel B: Additional strictly nondurables }}{\text { Dollar change in }}$} & \multicolumn{3}{|c|}{$\begin{array}{c}\text { Panel C: Additional nondurables } \\
\text { Dollar change in }\end{array}$} \\
\hline & $\begin{array}{c}\text { Food at } \\
\text { home }\end{array}$ & $\begin{array}{l}\text { Food away } \\
\text { from home }\end{array}$ & $\begin{array}{l}\text { Alcoholic } \\
\text { beverages }\end{array}$ & $\begin{array}{c}\text { Utilities, } \\
\text { Household } \\
\text { operations } \\
\end{array}$ & $\begin{array}{c}\text { Personal } \\
\text { care and } \\
\text { misc. } \\
\end{array}$ & $\begin{array}{c}\text { Gas, motor } \\
\text { fuel, public } \\
\text { transportation }\end{array}$ & $\begin{array}{l}\text { Tobacco } \\
\text { products }\end{array}$ & Apparel & Health & Reading \\
\hline$E S P$ & $\begin{array}{c}0.050 \\
(0.032)\end{array}$ & $\begin{array}{c}0.025 \\
(0.033)\end{array}$ & $\begin{array}{c}0.011 \\
(0.007)\end{array}$ & $\begin{array}{c}0.059 \\
(0.027)\end{array}$ & $\begin{array}{c}0.083 \\
(0.049)\end{array}$ & $\begin{array}{c}0.027 \\
(0.039)\end{array}$ & $\begin{array}{c}0.007 \\
(0.009)\end{array}$ & $\begin{array}{c}0.022 \\
(0.021)\end{array}$ & $\begin{array}{c}0.025 \\
(0.048)\end{array}$ & $\begin{array}{l}-0.001 \\
(0.003)\end{array}$ \\
\hline $\begin{array}{l}\text { Implied share of change } \\
\text { in non-durable spending }\end{array}$ & 0.16 & 0.08 & 0.04 & 0.19 & 0.27 & 0.09 & 0.02 & 0.07 & 0.08 & 0.00 \\
\hline $\begin{array}{l}\text { Avg. share of non- } \\
\text { durable spending }\end{array}$ & 0.23 & 0.11 & 0.01 & 0.23 & 0.04 & 0.16 & 0.01 & 0.06 & 0.15 & 0.01 \\
\hline
\end{tabular}

Notes: $\mathrm{N}=10,488$ for all regressions. All regressions also include the change in the number of adults, the change in the number of children, the age of the household, and a full set of month dummies. The sample includes only households receiving only on-time ESPs. Reported standard errors are adjusted for arbitrary within-household correlations and heteroskedasticity. All results are from 2SLS regressions where I(ESP) and the other regressors are used as instruments for ESP. 
Table 11: The propensity to spend on subcategories of durable expenditures

\begin{tabular}{|c|c|c|c|c|c|c|c|c|c|}
\hline $\begin{array}{r}\text { Dependent } \\
\text { variable: }\end{array}$ & \multicolumn{4}{|c|}{$\begin{array}{c}\frac{\text { Panel A: Subcategories of durable spending }}{\text { Dollar change in }} \\
\end{array}$} & \multicolumn{5}{|c|}{$\begin{array}{c}\frac{\text { Panel B: Subcategories of transportation }}{\text { Dollar change in }} \\
\end{array}$} \\
\hline$E S P$ & $\begin{array}{c}0.099 \\
(0.092)\end{array}$ & $\begin{array}{c}0.077 \\
(0.099)\end{array}$ & $\begin{array}{l}-0.100 \\
(0.042)\end{array}$ & $\begin{array}{c}0.527 \\
(0.269)\end{array}$ & $\begin{array}{c}0.357 \\
(0.204)\end{array}$ & $\begin{array}{c}0.123 \\
(0.149)\end{array}$ & $\begin{array}{c}0.011 \\
(0.054)\end{array}$ & $\begin{array}{c}0.009 \\
(0.028)\end{array}$ & $\begin{array}{c}0.027 \\
(0.024)\end{array}$ \\
\hline $\begin{array}{l}\text { Implied share of change } \\
\text { in durable spending }\end{array}$ & 0.16 & 0.13 & -0.17 & 0.87 & 0.59 & 0.20 & 0.02 & 0.01 & 0.04 \\
\hline $\begin{array}{l}\text { Avg. share of } \\
\text { durable spending }\end{array}$ & 0.56 & 0.13 & 0.04 & 0.27 & 0.07 & 0.06 & 0.01 & 0.04 & 0.09 \\
\hline
\end{tabular}

Notes: $\mathrm{N}=10,488$ for all regressions. All regressions also include the change in the number of adults, the change in the number of children, the age of the household, and a full set of month dummies. The sample includes only households receiving only on-time ESPs. Reported standard errors are adjusted for arbitrary within-household correlations and heteroskedasticity. All results are from 2SLS regressions where I(ESP) and the other regressors are used as instruments for ESP . 
Figure 1: Economic stimulus payments during 2008

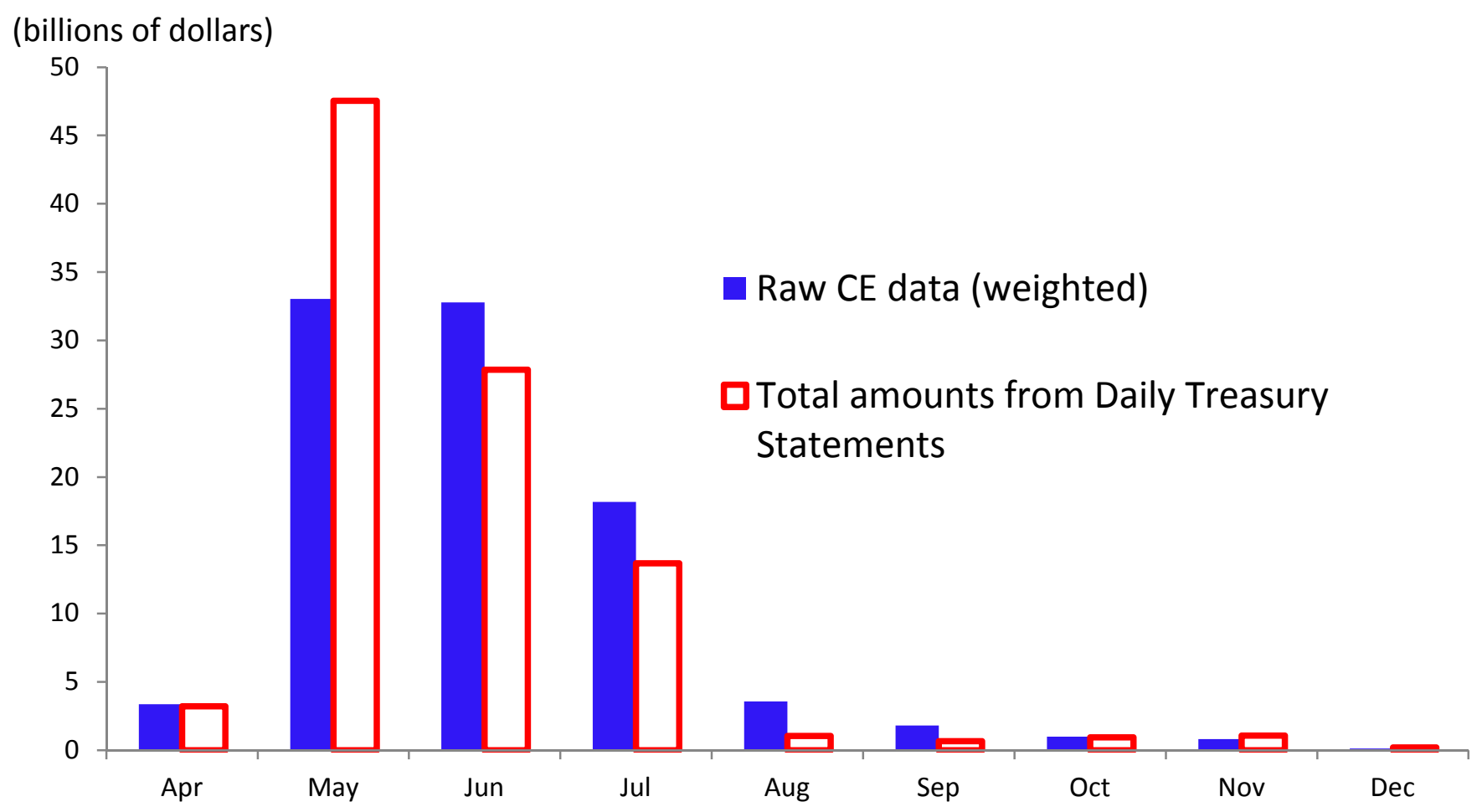

Notes: Source: Daily Treasury Statements and authors' calculations from the CE data. 


\section{Figure 1: Histograms of change in expenditure for ESP recipients during the program}

\section{Panel A: change in nondurable expenditure}

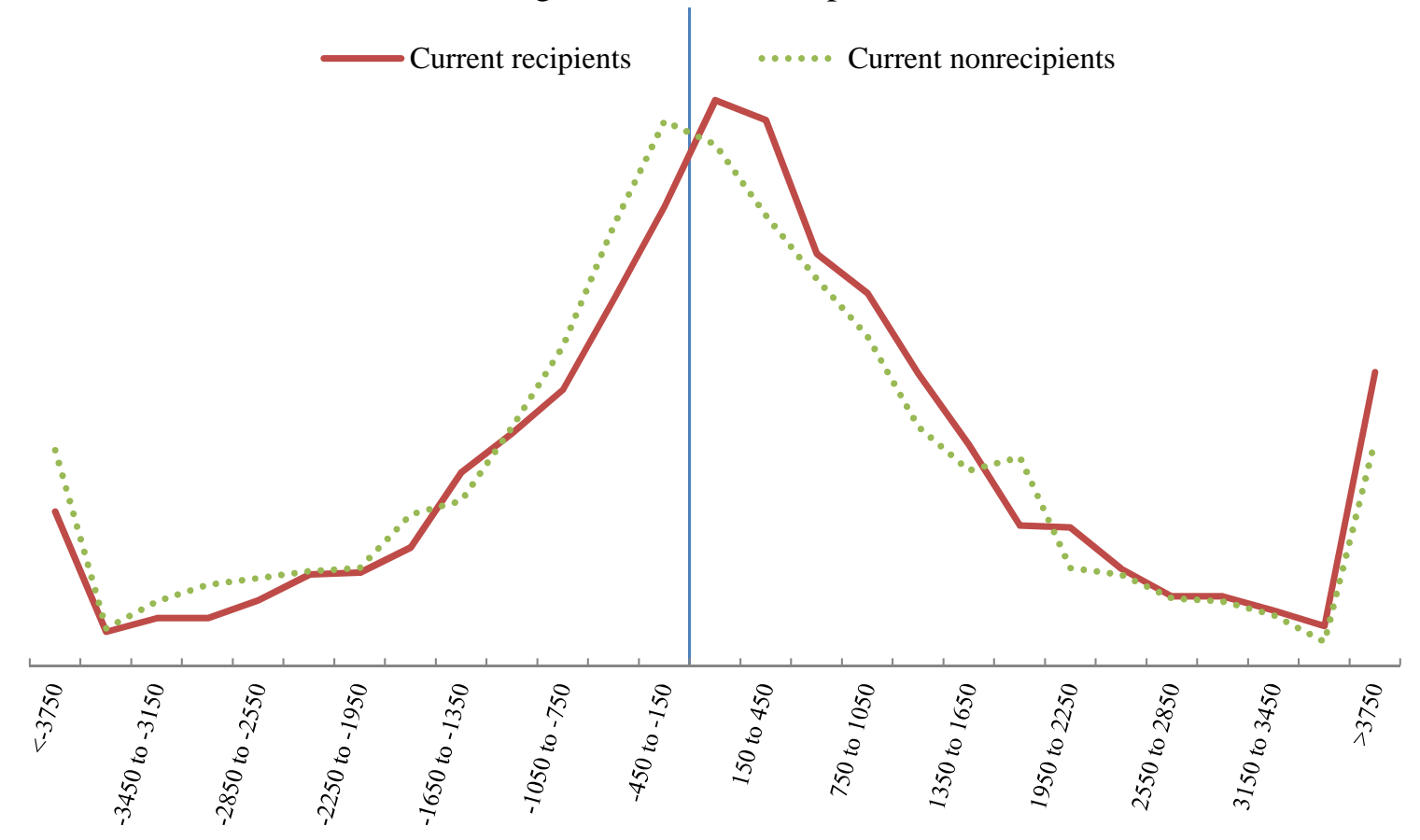

Panel B: change in total expenditure

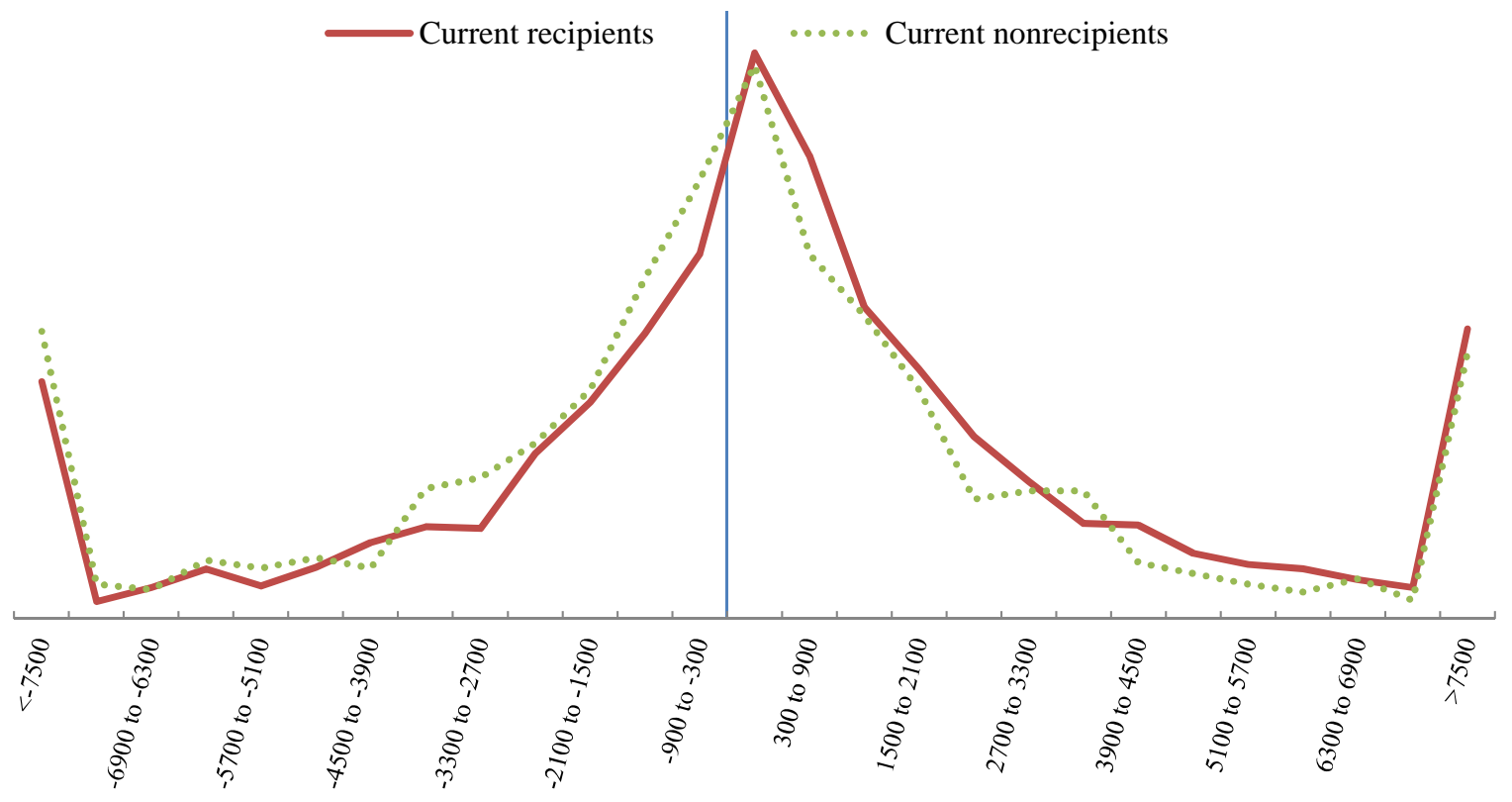

Notes: Plots are histograms of change in expenditures in household-periods. The sample of households includes only households receiving only on-time ESPs at some time. The sample period includes only periods in which some households report receiving on-time ESPs during the second three-month period covered in the change (interviews from June through October 2008). The total number of households is normalized to be equal across samples so that the histogram is a discrete estimate of the density function. 
Figure 3: Actual aggregate personal consumption expenditures and alternatives

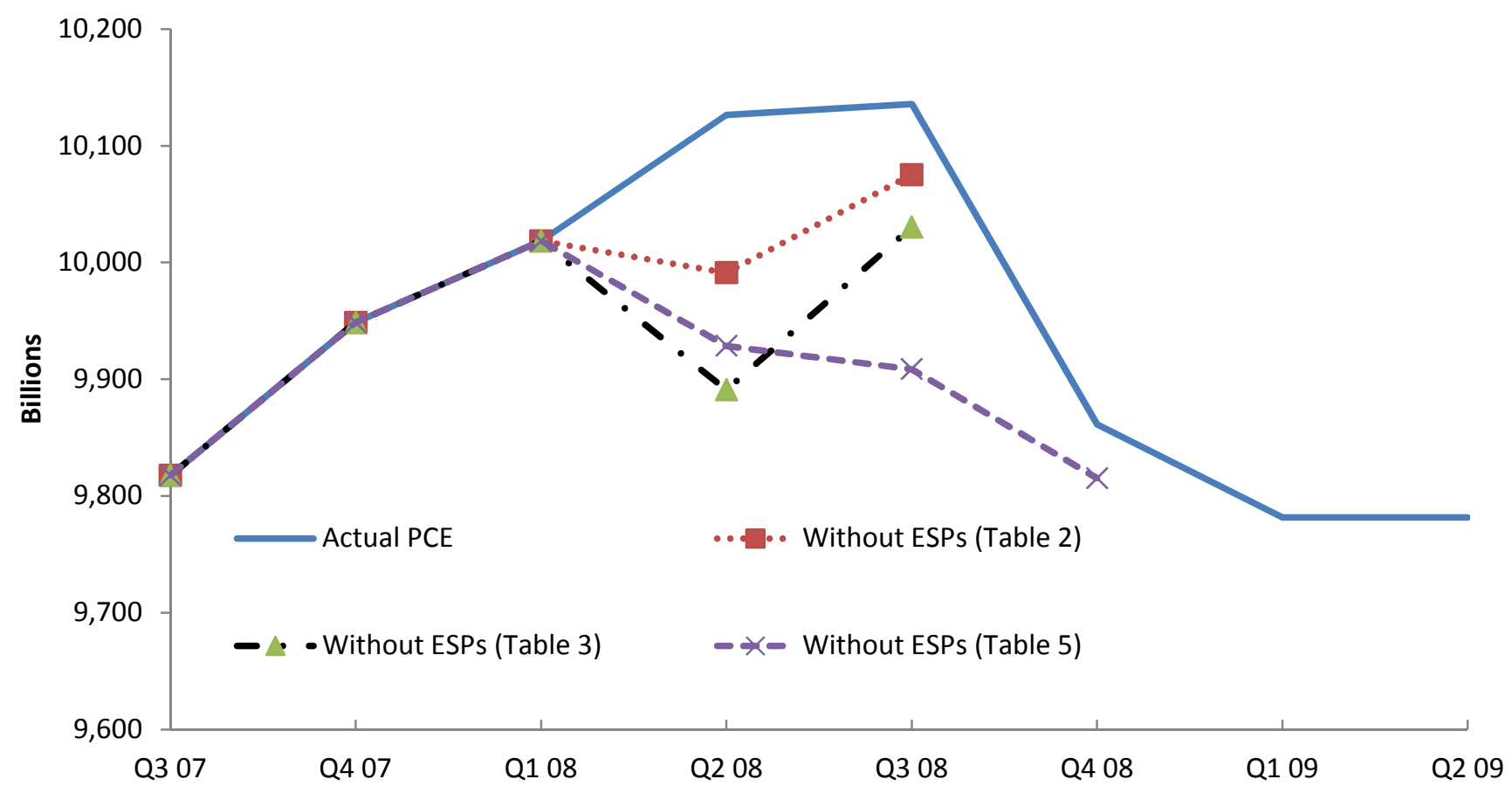

Notes: All calculations use estimates from instrumental variables specifications for total CE spending. Alternative scenarios subtract only the estimated direct effect of the stimulus payments on spending. The aggregate effect is calculated by applying the estimated average share of stimulus payments spent to the actual monthly time series of payments. We assume that the measured contemporaneous share spent is spent evenly over the month of receipt and the subsequent month, and that any lagged spending occurs evenly over the following three months. 